Challenges and opportunities of species distribution modelling of terrestrial arthropod predators

\title{
Mammola, Stefano
}

$2021-12$

Mammola , S , Pétillon , J , Hacala , A, Monsimet , J , Marti , S-L , Cardoso , P \& Lafage , D 2021 , ' Challenges and opportunities of species distribution modelling of terrestrial arthropod predators ' , Diversity and Distributions , vol. 27 , no. 12 , pp. 2596-2614 . https://doi.org/10.1111/ddi.1343

http://hdl.handle.net/10138/338818

https://doi.org/10.1111/ddi.13434

cc_by

publishedVersion

Downloaded from Helda, University of Helsinki institutional repository.

This is an electronic reprint of the original article.

This reprint may differ from the original in pagination and typographic detail.

Please cite the original version. 


\title{
Challenges and opportunities of species distribution modelling of terrestrial arthropod predators
}

\author{
Stefano Mammola $^{1,2}$ (D) | Julien Pétillon ${ }^{3}$ | Axel Hacala ${ }^{3}$ | Jérémy Monsimet ${ }^{4}$ (D) | \\ Sapho-Lou Marti $^{3}$ | Pedro Cardoso ${ }^{1}$ | Denis Lafage ${ }^{3,5}$
}

${ }^{1}$ Laboratory for Integrative Biodiversity Research (LIBRe), Finnish Museum of Natural History (LUOMUS), University of Helsinki, Helsinki, Finland

${ }^{2}$ Molecular Ecology Group (MEG), Water Research Institute (RSA), National Research Council (CNR), Verbania Pallanza, Italy

${ }^{3}$ UMR ECOBIO, Université de Rennes 1, Rennes, France

${ }^{4}$ Inland Norway University of Applied Sciences, Campus Evenstad, Koppang, Norway

${ }^{5}$ Department of Environmental and Life Sciences/Biology, Karlstad University, Karlstad, Sweden

\section{Correspondence}

Stefano Mammola, Laboratory for Integrative Biodiversity Research (LIBRe), Finnish Museum of Natural History (LUOMUS), University of Helsinki, Helsinki, Finland.

Emails: stefano.mammola@helsinki.fi; stefano.mammola@cnr.it

\section{Funding information}

European Commission, Grant/Award

Number: 882221

Editor: Raimundo Real

\begin{abstract}
Aim: Species distribution models (SDMs) have emerged as essential tools in the equipment of many ecologists, useful to explore species distributions in space and time and answering an assortment of questions related to biogeography, climate change biology and conservation biology. Historically, most SDM research concentrated on wellknown organisms, especially vertebrates. In recent years, these tools are becoming increasingly important for predicting the distribution of understudied invertebrate taxa. Here, we reviewed the literature published on main terrestrial arthropod predators (ants, ground beetles and spiders) to explore some of the challenges and opportunities of species distribution modelling in mega-diverse arthropod groups.

Location: Global.

Methods: Systematic mapping of the literature and bibliometric analysis.

Results: Most SDM studies of animals to date have focused either on broad samples of vertebrates or on arthropod species that are charismatic (e.g. butterflies) or economically important (e.g. vectors of disease, crop pests and pollinators). We show that the use of SDMs to map the geography of terrestrial arthropod predators is a nascent phenomenon, with a near-exponential growth in the number of studies over the past ten years and still limited collaborative networks among researchers. There is a bias in studies towards charismatic species and geographical areas that hold lower levels of diversity but greater availability of data, such as Europe and North America. Conclusions: Arthropods pose particular modelling challenges that add to the ones already present for vertebrates, but they should also offer opportunities for future SDM research as data and new methods are made available. To overcome data limitations, we illustrate the potential of modern data sources and new modelling approaches. We discuss areas of research where SDMs may be combined with dispersal models and increasingly available phylogenetic and functional data to understand evolutionary changes in ranges and range-limiting traits over past and contemporary time-scales.
\end{abstract}




\section{KEYWORDS}

bibliometrics, climate change, ecological niche models, MaxEnt, mechanistic models, nichebased models, predicted distribution, social network analysis, statistical modelling

\section{1 | INTRODUCTION}

A mainstream topic in ecology, biogeography and conservation biology is the extent to which climatic conditions affect species performance (Colinet et al., 2015; Rezende \& Bozinovic, 2019), which together with geographical and historical constraints ultimately modulates species niches and observed range boundaries (Bennett et al., 2021; Thomas, 2010). Obtaining a nuanced understanding of the factors conditioning species distributions has gained new urgency amid the current climate emergency (Ripple et al., 2020), insofar as changing climatic conditions are determining fast redistributions of species along latitudinal, elevational and other spatial gradients (Chen et al., 2011; Lenoir et al., 2020). As global climate change redefines the geography of life, we are becoming spectators of a large-scale experiment of complex ecological responses (Halsch et al., 2021; Román-Palacios \& Wiens, 2020), where interactions among previously isolated species can quickly occur (Krosby et al., 2015), invasions of novel areas by alien species are becoming routine (Hellmann et al., 2008; Liu, Clarke, et al., 2020; Liu, Blackburn, et al., 2020), and unnoticed extinctions are potentially taking place on a daily basis (Barnosky et al., 2011; Cardoso, Barton, et al., 2020; Hughes et al., 2004). Therefore, mapping the diversity of life has never been so urgent (Santini, Antão, et al., 2021).

Over the years, ecologists and statisticians have developed an assortment of methods for modelling the niche and distribution of species in space and time, several of which fall under the umbrella of correlative species distribution models or ecological niche models (Box 1). For simplicity, we will hereafter refer to these as "species distribution models" (SDMs), while redirecting the interested readers to semantic discussions (Peterson et al., 2012; Sillero, 2011; Warren, 2012). Researchers have used SDM techniques for mapping the distribution of organisms in a variety of systems, although the number of applications across habitats and the tree of life have not been equal. For example, while the use of SDMs has grown exponentially in the terrestrial realm from the early 2000s onwards (Araújo et al., 2019; Lobo et al., 2010; Robinson et al., 2011), applications in systems where three-dimensionality is an important feature-for example marine ecosystems (Melo-Merino et al., 2020; Robinson et al., 2017), tree canopies (Burns et al., 2020), soils (Schröder, 2008) and caves (Mammola \& Leroy, 2018)-have lagged behind. Also, applications of SDMs in animals have concentrated mostly on vertebrates (Titley et al., 2017), while studies on arthropod groups remain scarcer, although recently increasing (Figure 1).

This paucity of SDM studies is possibly related to a number of arthropod-specific modelling challenges. First, arthropods often are small organisms that move in small spatial scales, strongly influenced by microclimatic conditions and microhabitat structure (Pincebourde \& Woods, 2020). These characteristics are hardly captured by the ubiquitous bioclimatic variables derived from remote sensing at relatively large spatial scales (Lembrechts et al., 2020; Potter et al., 2013). Second, arthropods often have short life cycles with wide population abundance fluctuations from season to season and strong metapopulation dynamics, making it difficult to determine what their real, constantly changing range is. Third, occurrence data sets for poorly known arthropod species are likely to be severely spatially and temporally biased, affecting our appreciation of their real distribution patterns (Hughes et al., 2021). Thus, arthropods pose particular modelling challenges that add to the ones already present for vertebrates, but they should also offer opportunities for future SDM research as data and new methods are made available (Maino et al., 2016).

Natural history is indeed entering its next-generation phase (Anderson et al., 2021; Jarić et al., 2020; Tosa et al., 2021), one characterized by increasingly available data (not only distribution data but also species traits and phylogenies) that can be routinely integrated in our modelling exercises. This is made possible by a parallel development of new methods, ranging from computationally fast multispecies modelling platforms (Pichler \& Hartig, 2021) to flexible techniques able to account for traits (phenotypic plasticity) and genetic data in making predictions (Brewer et al., 2016; Bush et al., 2016; Garzón et al., 2019), along with tools to ease model interpretability (Ryo et al., 2021). As entomology is entering a nextgeneration phase too (Høye et al., 2021; Liu, Clarke, et al., 2020; Liu, Blackburn, et al., 2020), in all likelihood these advances will soon cascade to positively affect our understanding of the distribution of less studied arthropod groups.

Not only anticipating this progress but also considering the recent upsurge of studies discussing an "insect apocalypse" and the related calls for understanding the drivers of arthropod extinction risk (Cardoso, Barton, et al., 2020; Cardoso \& Leather, 2019; Wagner et al., 2021), we conducted a systematic mapping of the literature to understand and synthesize trends in the use of SDMs in arthropod research. We explored these topics through the lens of the literature on dominant terrestrial arthropod predators: ants (c. 30,000 described species; Parr et al., 2017), ground beetles (c. 39,300 species; Lorenz, 2019) and spiders (c. 49,600 species; World Spider Catalog, 2021). We begin by conducting a systematic literature search focused on SDM use in our focal group. Then, to put our survey in perspective, we compare the volume of literature with that on other key terrestrial invertebrate and vertebrate groups. By means of bibliometric analyses, we explore the geography of SDM applications and networks of collaborations among researchers working on terrestrial arthropod predators. Subsequently, we review the main areas of application of SDMs in terrestrial arthropod research, highlighting which ecological factors emerged as important in driving predicted distribution patterns. Building upon this quantitative evidence, we discuss challenges and opportunities of 


\section{BOX 1 A general definition of species distribution models (SDMs) and their domain of applicability}

As a broad and general definition, species distribution modelling implies using some statistical algorithms to explore the relationship between species occurrences (typically georeferenced localities) and environmental variables. Once this relationship is determined, the model is used to characterize the ecological niche of a given species. This is usually achieved by projecting a probability surface or a habitat suitability map into a geographical space to represent its potential range of distribution (Guisan et al., 2017). These models can be constructed using a wide range of algorithms including linear and additive regressions (Elith \& Leathwick, 2009), symbolic regressions (Cardoso, Branco, et al., 2020), tree-based machine learning (Zhang et al., 2019), maximum entropy models (Elith et al., 2011) and more. Given the large variety of life histories and data sources, the best modelling algorithm and approach necessarily changes, with no universal best solutions (Qiao et al., 2015).

Whereas the first paper relying on species distribution modelling is now over three decades old [e.g. the first applications of the algorithm BIOCLIM can be traced back to 1986 (Booth, 2018)], there has been an acceleration in the use of these tools in just the last two decades (Araújo et al., 2019; Lobo et al., 2010; Figure 1). This trend was probably due to the increase in occurrence data (Wüest et al., 2020; Zhang, 2017) and easy-to-use, often automated statistical packages that perform species distribution modelling (reviewed in Angelov, 2019). These methods have become popular in the toolkit of many ecologists, being useful to answer a range of questions. Not only are SDMs routinely used to describe species distributions, they have also proved important to assist and complement taxonomic studies (Rödder et al., 2010) and to set conservation agendas (Guisan et al., 2013). Furthermore, given that these models are transferable in space and time (Yates et al., 2018), they find applications in studies on climate change (Dormann, 2007; Santini et al., 2021), historical biogeography (Peterson, 2009) and invasion biology (Liu, Clarke, et al., 2020; Liu, Blackburn, et al., 2020; Peterson, 2003), among other topics.

\section{2 | LITERATURE SURVEY AND QUANTITATIVE ANALYSES}

\subsection{Systematic literature search and metadata extraction}

Between 20 and 24 November 2020, we searched on the Web of Science (Clarivate Analytics) for articles relying on SDMs to predict distributions of terrestrial arthropod predators (ants, ground beetles and spiders) and, for comparative purposes, other terrestrial vertebrate and invertebrate groups (Table 1). For each taxonomic group considered, we found and extracted papers using the following general query:

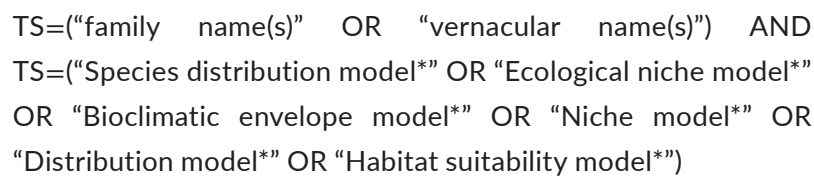

where TS denotes a search for "Topic," and the asterisk (*) is a regular expression used to match all words including that string of characters (e.g. "model*" matches "models," "modelling," and "modelled"). See Appendix S1 for the list of specific queries.

We exported all results into the online review application Rayyan (Ouzzani et al., 2016) for title, keywords and abstract screening, whereby we excluded by-catches of papers not actually dealing with SDMs or our model species (e.g. our search for the keyword "spiders" also captured papers dealing with spider monkeys, genus Ateles) (Table 1). Furthermore, for ants, ground beetles and spiders, we manually inspected papers to extract specific data (Appendix S2). We recorded the geographical extent of each study and all the species modelled. We classified the type of predictors used, their resolution, and the SDM algorithm(s) and modelling protocol employed. Specifically, we coded the modelling protocol under three main categories: single algorithm, when studies just applied one modelling technique; ensemble of models, when the authors applied a plethora of different models (e.g. generalized linear model, generalized additive model, random forest, MaxEnt) and ensemble predictions of individual models via an averaging formula or algorithm (Araújo et al., 2019); and no silver bullet (Qiao et al., 2015), when the authors applied a number of algorithms (e.g. generalized additive model, boosted regression tree, symbolic regression) and only selected one for projecting the distribution based on some measure of algorithm performance. Finally, we summarized the key results of each study (Appendix S2).

\section{2 | Data analyses}

We conducted analyses in R 3.6.3 (R Core Team, 2020) and visualized data using the ggplot2 R package (Wickham, 2016) and QGIS (Open Source Geospatial Foundation Project, 2020). The complete data set and $\mathrm{R}$ code used for the analyses are available on GitLab (https://gitlab.com/DenisLafage/sdm_review).
SDM research on terrestrial arthropod predators and delineate potential future lines of enquiry and promising areas of research where SDMs may be combined with other modelling tools and data sources to obtain mechanistic descriptions of species distributions and their shifts within a global change perspective. 
FIGURE 1 Cumulative number of articles per year. (a) Comparison between arthropods and vertebrates; (b) comparison between main arthropod groups
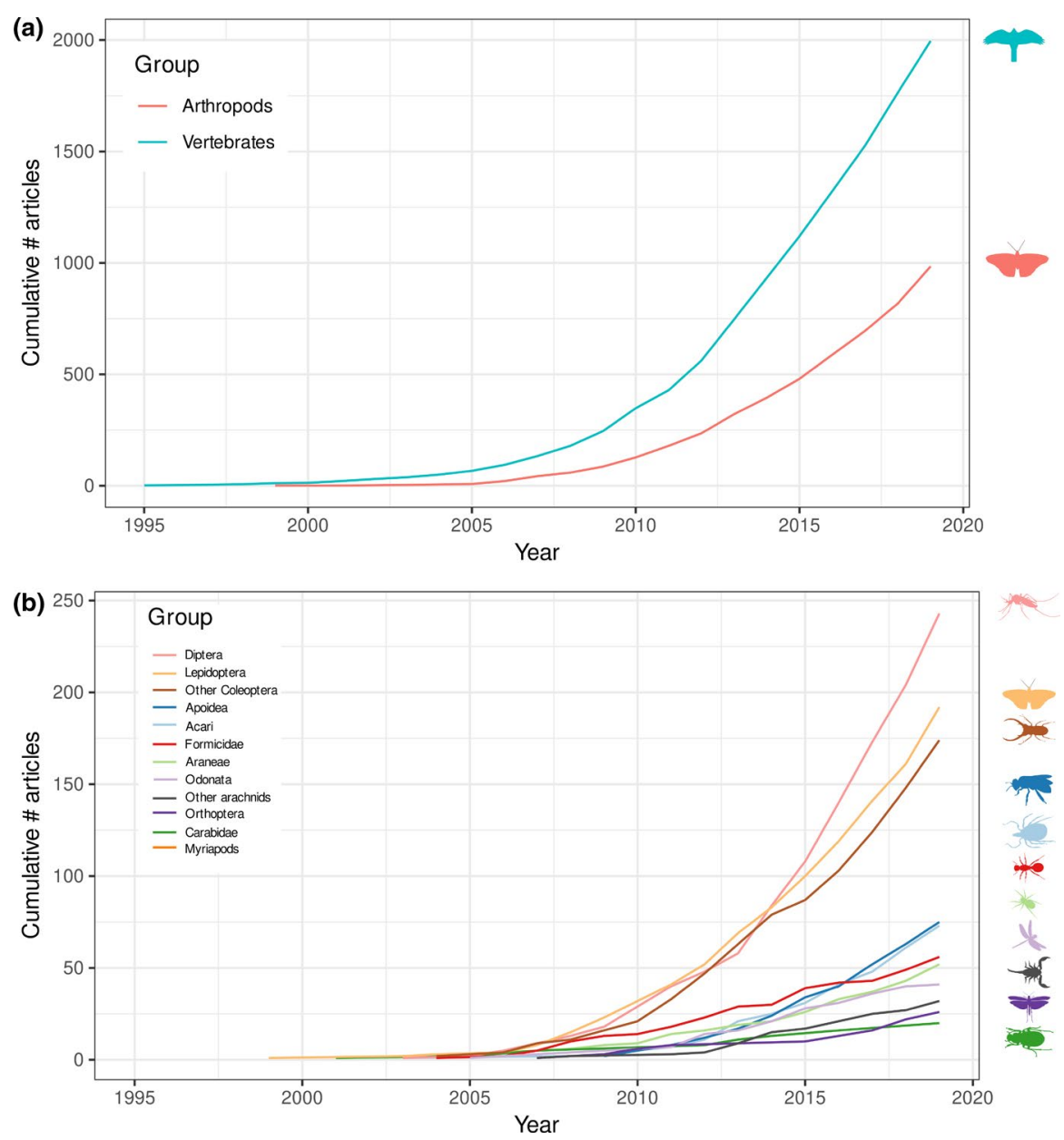

We analysed bibliometric data regarding the articles on ants, ground beetles and spiders with the bibliometrix $\mathrm{R}$ package (Aria \& Cuccurullo, 2017). In order to map the production of articles per country for each group, we assigned articles to a country based on the affiliations of all the authors at the time when each article was published. In order to identify the most influential papers for researchers dealing with modelling of terrestrial arthropod predators distributions, we used a weighted co-citation network. Initially introduced for bibliometric research, co-citation networks have proved useful to identify key literature items acting as bridges between disciplines (Trujillo and Long, 2018). A particular article is included in the network when it is cited by at least two papers from the data set under study (Batagelj \& Cerinšek, 2013). The number of co-citations is the number of times two articles are cited together. Furthermore, we built a collaboration network to identify the existence of bridges among scientists working on ants, ground beetles and spiders.

\subsection{Caveats in the interpretation of the survey}

Due to our search strategy in the Web of Science and selection of keywords (Appendix S1), we did not capture all possible studies on SDMs dealing with our focal groups. For example, we missed some studies on taxonomy that used SDMs to assist species delimitations, as these did not mention the methodology in their keywords, title or abstract. Similarly, SDMs have recently begun to be routinely used for assessing terrestrial arthropod risk of extinction (Branco et al., 2019; Fukushima et al., 2019; Milano et al., 2021; Seppälä et al., 2018a, 2018b, 2018c, 2018d), but most of these studies were missed for the same reason. Furthermore, for many groups, especially vertebrates, the authors may not mention the higher taxonomic ranks included in our query but exclusively the species, genus or family, which will not be captured. We also acknowledge that our search was not linguistically exhaustive as we only included articles in English (Konno et al., 2020). As a result, our estimation of the volume of the literature on the focal groups should be taken as an approximation of the real number of studies. While we operated under the assumption that the biases were homogeneously distributed across all taxonomic groups, allowing us to compare them and to draw general inferences, still the comparison of absolute numbers of studies across taxa should be taken with caution (e.g. in Figure 1).

\section{3 | TAXONOMIC BIAS IN SDM RESEARCH ON ARTHROPODS}

While SDM studies based on comprehensive samples of vertebrate species are becoming routine (Liu, Clarke, et al., 2020; Liu, Blackburn, 
TABLE 1 Number of articles returned by the queries on Web of Science (WOS) and number of articles kept after title, keywords and abstract screening

\begin{tabular}{|lcc|}
\hline Group & $\begin{array}{l}\text { No. of papers } \\
\text { on WOS }\end{array}$ & $\begin{array}{l}\text { No. of } \\
\text { papers kept }\end{array}$ \\
\hline Spiders (Araneae) & 74 & 55 \\
\hline Ground beetles (Carabidae) & 32 & 24 \\
\hline Ants (Formicidae) & 108 & 51 \\
\hline Other arachnids & 37 & 34 \\
\hline Mites and ticks (Acari) & 159 & 110 \\
\hline Molluscs (Gastropoda) & 164 & 121 \\
\hline Flies (Diptera) & 454 & 320 \\
\hline Grasshoppers and crickets & 59 & 34 \\
\hline (Orthoptera) & & \\
\hline Beetles other than Carabidae & 313 & 183 \\
\hline (Coleoptera) & & 253 \\
\hline Butterflies (Lepidoptera) & 391 & 42 \\
\hline Dragonflies and damselflies & 50 & 81 \\
\hline (Odonata) & 116 & 347 \\
\hline Bees (Apoidea) & 529 & 412 \\
\hline Reptiles (Reptilia) & 652 & 617 \\
\hline Amphibians (Amphibia) & 854 & 930 \\
\hline Mammals (Mammalia) & 1,411 & \\
\hline Birds (Aves) & & \\
\hline
\end{tabular}

et al., 2020; Thuiller et al., 2019), our literature survey emphasizes how just a small fraction of terrestrial arthropod predators have been subjected to the attention of modellers. By comparing the volume of SDM literature on vertebrates versus invertebrates, we observed a similar exponential increase in the number of studies for both groups, with an inflection point after 2010 (Figure 1a). However, the total number of studies was greater for vertebrates (67\%) than invertebrates, and this difference would be even greater if these numbers are relativized to the total number of known vertebrate and arthropod species. This is a typical pattern that is partly explained by the fact that there is more available information on vertebrates (e.g. distribution data; Troudet et al., 2017) and partly the result of a cognitive bias in terms of researcher's subjective preferences for certain taxa over others (Clark \& May, 2002) - what has been termed by entomologists "institutional vertebratism" or "taxonomic chauvinism" (Leather, 2009a, 2009b). The few available studies on arthropods are drops in the ocean when considering the number of described and as yet undescribed species of insects (Stork, 2018) and spiders (Agnarsson et al., 2013).

Taxonomic bias towards certain groups exists also among articles dedicated to arthropods (Cardoso, 2012; Leandro et al., 2017). For example, butterflies are among the most studied in SDM studies (6.4\%), which once again may be due to a greater availability of information (Brereton et al., 2011; van Swaay et al., 2008; Thomas, 2005), and which in turn might be driven by aesthetic characteristics. Other well-studied groups are those relevant from an economic point of view, such as vectors of diseases (Diptera, 8.9\%), crop pests (other beetles, 6.6\%) and pollinators (Apoidea, 3.2\%) (Figure 1b).

As for our focal groups, we found that although spiders and ground beetles outnumber ants in terms of described species, the number of species studied was considerably higher for ants. This may be linked to the topic of articles, with most papers focusing on one of the numerous invasive ant species-it is likely that a few globally relevant invasive ant species (e.g. Argentine ant, fire ant) allow myrmecologists to obtain research funding, thus attracting most research attention (Holway et al., 2002; Silverman \& Brightwell, 2008).

Inevitably, the few studies on ants, ground beetles and spiders have often been opportunistic, largely reflecting the specific interests of the few authors who have ventured to explore the potential of SDMs in terrestrial arthropod research. For example, this is evident when looking at a sample of papers on spiders-most studies focused on large-sized, taxonomically unique and/or charismatic species (Decae et al., 2019; Hamilton et al., 2016; JiménezValverde et al., 2011; Wang et al., 2018), taxa of medical importance (Planas et al., 2014; Taucare-Ríos et al., 2018; Wang et al., 2018) or taxa inhabiting peculiar habitats that are the interest of certain authors, such as caves (Mammola et al., 2018, 2019; Pavlek \& Mammola, 2021).

\section{4 | GEOGRAPHICAL BIAS IN SDM RESEARCH ON ARTHROPODS}

The geography of studies, as inferred from author affiliations, revealed how the production of SDM papers on ants, ground beetles and spiders is mostly concentrated in North and South America and Europe (Figure 2). These are geographical areas that hold lower levels of diversity but greater availability of data. There were, however, some conspicuous differences among groups. For ants, modelled species are mostly in North and South America and Europe (Figures S1 and S2); only 15 studies modelled species distribution worldwide. For spiders and ground beetles, most studies focused on European species (Figures S3-S6), and only three and one studies/y, respectively, had worldwide coverage. There were considerably more ant species, which have been studied with SDMs than spiders and ground beetles.

\section{5 | INFLUENTIAL PAPERS, COLLABORATIONS AND TOPICS}

The co-citation network allowed us to identify key articles co-cited by the studies included in our survey (Figure 3). As expected, most co-cited papers were methodological rather than arthropod-specific papers. The top-cited papers were Phillips et al. (2006) and Hijmans et al. (2005), respectively, the reference for the algorithm MaxEnt and for the most widely used global climate database (WorldClim). Among the less co-cited but still influential papers, there were several references to phylogenetic methods, suggesting that a number 
of articles are potentially integrative research using multiple lines of evidence to deal with species delimitation (Ferretti et al., 2019; Ross et al., 2010) and historical biogeography (Magalhaes et al., 2014; Mammola et al., 2015; Planas et al., 2014; Solomon et al., 2008).

Network analysis also revealed highly structured collaboration hubs around the three groups of interest (Figure 4). Observed collaboration hubs were strongly bound but limited in size, with only four cases of inter-group collaborations (ants-ground beetles, ants-spiders and ground beetles-spiders). Two cases were the result of multi-taxa studies (Christman et al., 2016; JiménezValverde et al., 2009), and two were related to authors involved in articles dealing with two different groups: Williams S.E. (Staunton et al., 2014; Steiner et al., 2008) and Peterson A.T. (Peterson \& Nakazawa, 2008; Planas et al., 2014; Roura-Pascual et al., 2009, 2004, 2006).

Articles dealing with ants primarily focused on climate change (33.9\% of studies) and invasion biology (30.4\%). Many studies often dealt with both topics simultaneously (23.2\%) as these topics often go hand in hand, with researchers seeking to predict the future spread of alien species in climate change scenarios.

The research spectrum of articles dealing with spiders was more diversified, with studies using SDMs to explore the environmental drivers of species distribution (28.6\%), to predict distributions under future climate change (33.4\%) and to assist species delimitation (26.8\%), as well as other miscellaneous topics (19.6\%). Contrary to ants, only $7.1 \%$ of studies on spiders dealt with invasion biology, probably on account of the reduced number of globally important known invasive spiders (Nentwig, 2015).
Finally, the focus of articles dealing with ground beetles was almost entirely climate change $(52.6 \%)$ and the drivers of species distribution (36.8\%), with only two papers dealing with biological invasions.

\section{I HOW ARE WE MODELLING ARTHROPOD PREDATOR DISTRIBUTION?}

\section{1 | Algorithms}

A large majority of articles we reviewed used a single algorithm (for ants, ground beetles and spiders, $79.6 \%, 94.7 \%$ and $80.4 \%$, respectively) or ensemble (24.1\%, 5.3\% and $14.3 \%$, respectively) for modelling species distributions, whereas no silver bullet use was sporadic and only in spider-related articles (7.1\%). A total of 33 different algorithms were used in the studies we reviewed. For all taxonomic groups, MaxEnt was the most used algorithm (Figure 5), as also emphasized by the co-citation network (Figure 3). This is a recurrent pattern in the latest SDM research, as found for the research in other animal groups (e.g. bats; Razgour et al., 2016). This trend is probably due to the fact that MaxEnt is a presence-background technique, allowing users to overcome some of the difficulties associated with obtaining reliable absence data in the light of imperfect detection. Moreover, MaxEnt has proved to be a robust species distribution modelling technique according to comparative studies (Elith et al., 2006, a highly co-cited reference in our data set as shown in Figure 3).

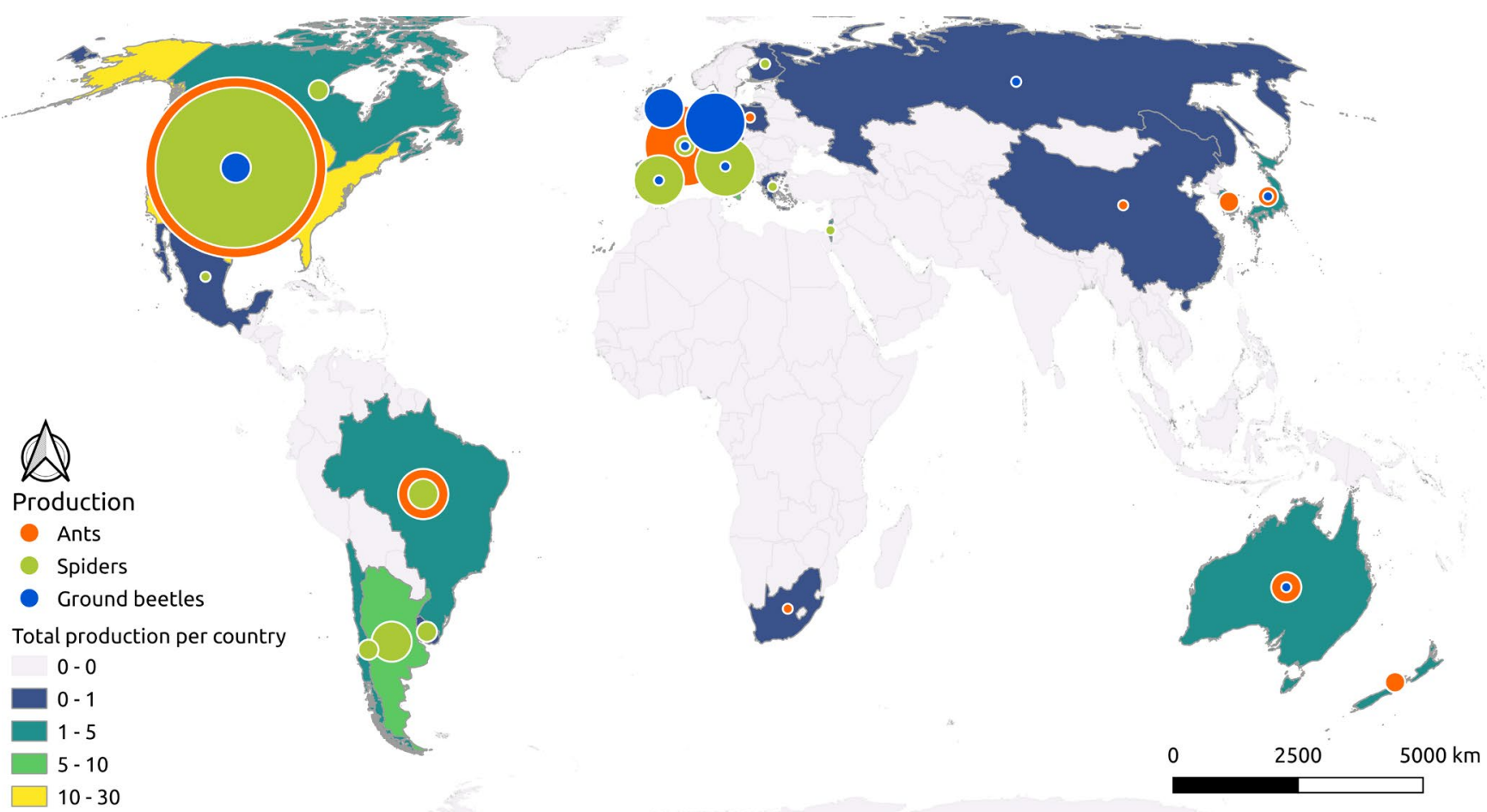

FIGURE 2 Production of studies per country for the three groups. Papers were attributed to a country based on the affiliations of the authors using the bibliometrix package 
MaxEnt

Ecological Niche Models

Model accuracy / selection

Phylogenetic

Invasion / Conservation ecology

Species Distribution Model

Climate change

Climate data

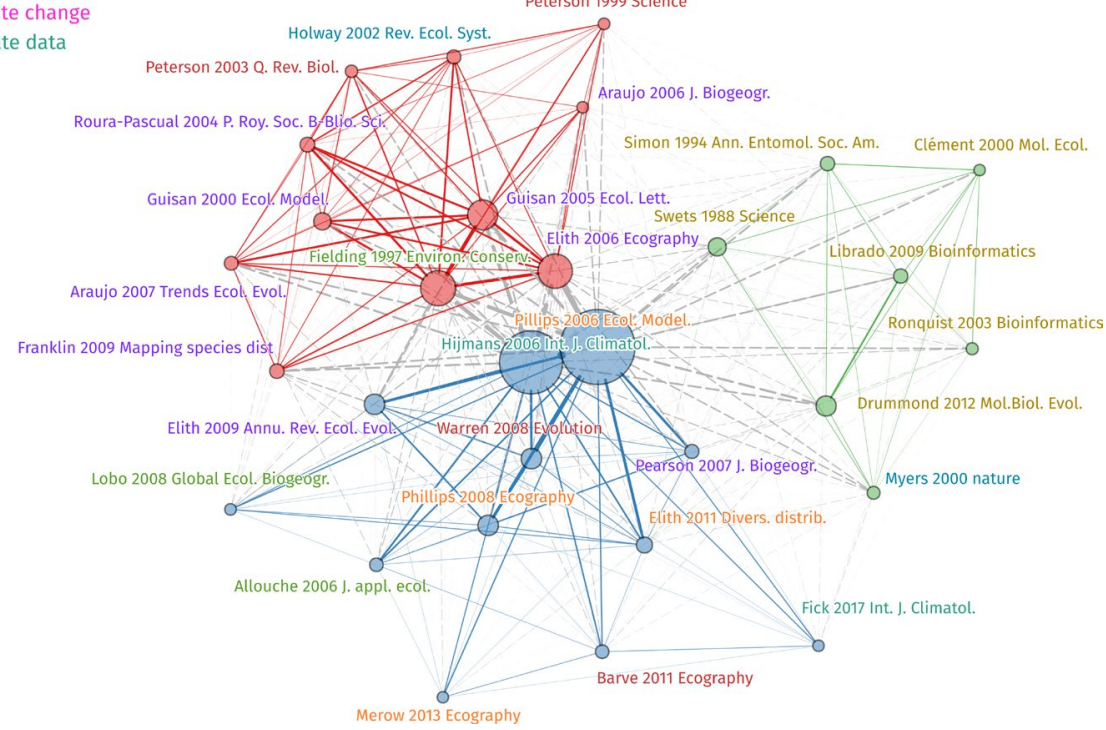

FIGURE 3 Weighted co-citation network for the top 30 cited papers in the entire data set (ants, ground beetles and spiders). The size of the vertex is proportional to the number of articles citing a given reference. The colours of the links and vertex reflect citation clusters. The colour of the text corresponds to the paper theme

\section{Collaboration Network}

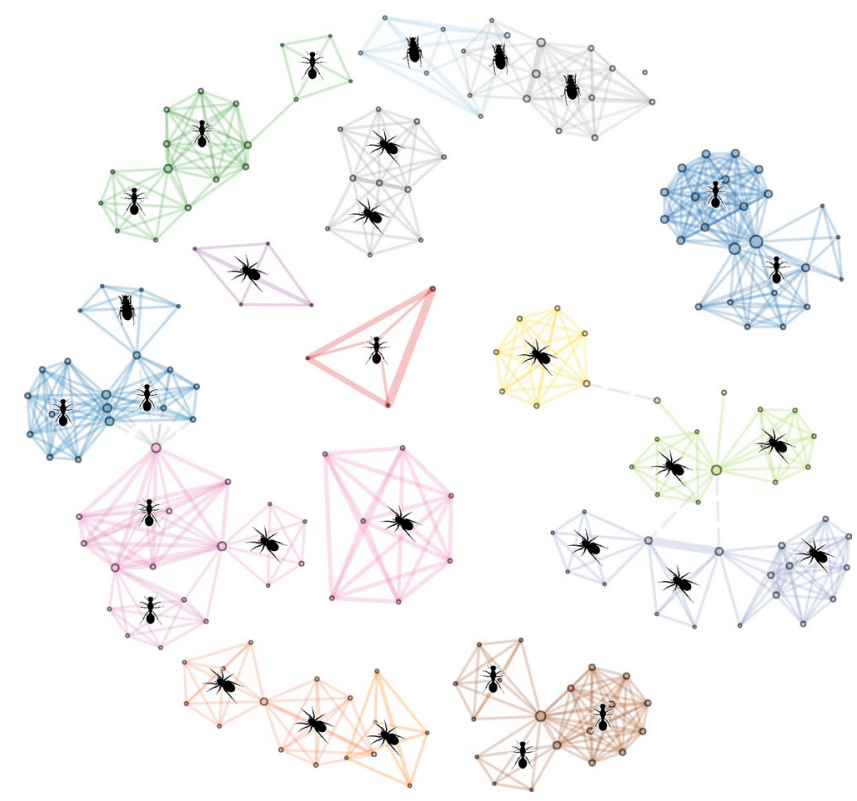

FIGURE 4 Collaboration network between authors. Colours represent clusters of collaboration and pictograms the group targeted. For readability, the network is restricted to those papers with at least one author having two articles in the data set. This represents 64 articles (out of 103) and 211 authors (out of 355)

Despite the large number of algorithms tested, even per article (up to 14), it remains unclear whether one algorithm rather than another is more suitable for modelling the distribution of terrestrial invertebrates. To the best of our knowledge, no comparative studies on algorithm performance focused on invertebrates are available.
More empirical comparisons of the performance algorithms in the context of terrestrial invertebrate research would be needed (Araújo et al., 2019; Qiao et al., 2015).

\section{2 | Environmental variables}

Bioclimatic variables were by far the most used predictors to model and explain species distributions (Table 2) for the three focal groups. This is partly due to the broad availability of free high-resolution climatic variables [e.g. CHELSA (Karger et al., 2017), CliMond (Kriticos et al., 2012) and WorldClim 2 (Fick \& Hijmans, 2017)], and partly reflects the true importance of climate as a limiting factor for species distribution (Muñoz \& Bodensteiner, 2019), especially climatic extremes (Román-Palacios \& Wiens, 2020). Climatic variables, in fact, were selected as important in virtually all analysed studies (Table 2). Note, however, that this may be systematic of a wider bias to choose data that are preprocessed, with little effort to select appropriate variables given the biology of the species (Fourcade et al., 2018; van de Pol et al., 2016).

Topography, soil and land use, and habitat variables are used less often, possibly due to greater limitations in their availability. Nevertheless, when used, these non-climatic factors were often selected as important in modelling the distribution (>65\% for ants and $>80 \%$ for spiders and ground beetles; Table 2 ).

Importantly, most environmental rasters used today for developing SDM achieve a maximum resolution of 30 arc.sec (cell size c. $1 \mathrm{~km}^{2}$ at the equator), which is excellent but might not be enough in the case of invertebrates that are known to respond to microclimatic characteristics over spatial scales of millimetres to metres (Potter et al., 2013; Suggitt et al., 2018). This is a key impediment that currently limits our ability to fully model the niche and distribution of 
FIGURE 5 Number of articles using a given algorithm for species distribution models by year and group. To improve readability, only algorithms used at least five times in the entire data set are shown. ANN, artificial neural network; CT, classification tree; FDA, flexible discriminant analysis; GAM, generalized additive model; GARP, genetic algorithm for rule-set production; GBM, generalized boosting model; GLM, generalized linear model; MARS, multiple adaptive regression spline; MaxEnt, maximum entropy

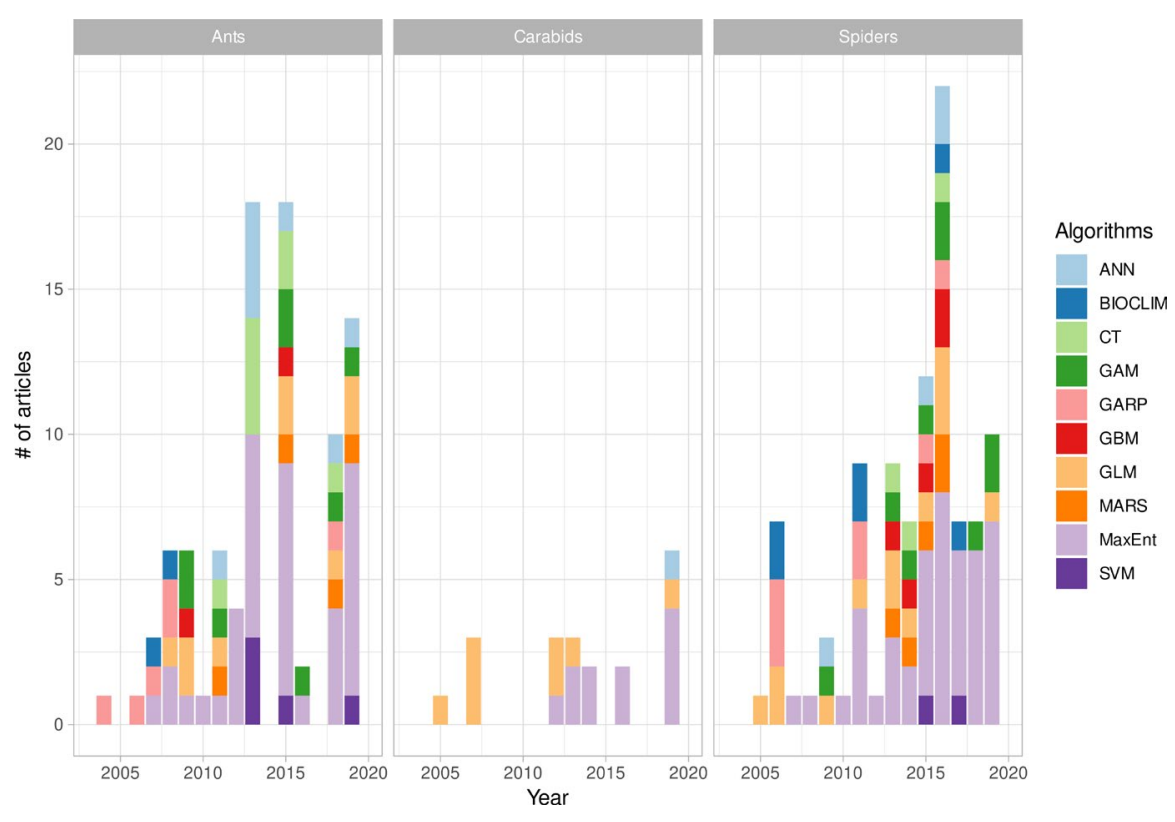

TAB LE 2 Percentage of studies predicting distribution in the past, present and future, using different types of predictor variables and where a given predictor variable type was selected in the best models (values in brackets)

\begin{tabular}{llll} 
& Ants & $\begin{array}{l}\text { Ground } \\
\text { beetles }\end{array}$ & Spiders \\
\hline $\begin{array}{l}\text { Projection } \\
\text { Past }\end{array}$ & 10.7 & 22.2 & 21.4 \\
Present & 87.5 & 61.1 & 96.4 \\
Future & 28.6 & 22.2 & 19.6 \\
\hline Predictor variables & & & \\
Climate & $92.9(100)$ & $77.8(100)$ & $98.2(100)$ \\
Soil & $19.6(65)$ & $27.8(100)$ & $10.7(80)$ \\
Geology & $5.4(0)$ & $11.1(0)$ & $10.7(33.3)$ \\
Topography & $25.0(73.6)$ & $27.8(100)$ & $41.1(80)$ \\
Habitat & $28.6(73.9)$ & $38.9(100)$ & $21.4(80)$ \\
\hline Mechanistic explanations & & & \\
Species traits & 8.9 & 0.0 & 3.6 \\
Ecophysiology & 5.5 & 0.0 & 0.0 \\
Genetic & 21.4 & 22.2 & 26.8 \\
\hline
\end{tabular}

terrestrial arthropods. In the analysed literature, mean variable resolution was rather similar for ants and ground beetles [respectively, 314.9 arc.sec $(\max =1.4 \mathrm{arc} . \mathrm{sec})$ and $414.7 \mathrm{arc} . \mathrm{sec}(\max =0.05 \mathrm{arc}$. $\mathrm{sec})$ ]. The mean resolution was higher for spiders (171.7 arc.sec ( $\max$ $=1.4$ arc.sec)).

\section{3 | Mechanistic models and alternative data sources}

The integration of SDM use with species functional traits and ecophysiological data was scarce. For ants, $10.2 \%$ of articles used traits and $6.2 \%$ ecophysiological data. For spiders, $2.4 \%$ of articles used functional traits and none ecophysiological data. For ground beetles, no articles used functional traits or ecophysiological data. In the few instances where similar variables were considered, these were not directly incorporated as predictors in the model but rather discussed in comparison with the modelled distribution. For the three groups, between $20 \%$ and $25 \%$ of papers used phylogenies, but without directly incorporating the phylogenetic information into the models (Table 2).

\section{7 | SOLUTIONS TO ALLEVIATE DATA LIMITATIONS}

The scarcity of data has been pointed out as one of the key limitations to our understanding of the drivers of biodiversity change in invertebrates (Cardoso \& Leather, 2019), as summarized in a number of so-called biodiversity shortfalls (Cardoso et al., 2011; Ficetola et al., 2019; Hortal et al., 2015; Lopes-Lima et al., 2021). SDMs may help us to combat some of these impediments by identifying unexplored regions of high environmental suitability for improving the geographical gaps in species distributions (i.e. tackling the Wallacean shortfall), by identifying the environmental drivers of these distributions (Hutchinsonian shortfall) and even by suggesting suitable sites for further sampling (Linnean shortfall). However, the SDM construction in itself requires robust and high-quality distribution data, creating a loop that is difficult to break. We provide below a few promising avenues for future improvements.

\section{1 | Distribution data}

A quick search for any bird species in the Global Biodiversity Information Facility (www.gbif.org) reminds us that it is unlikely we will ever possess for arthropods the same amount and quality of data 
available for vertebrates. Arthropods are simply too ubiquitous in space and time (Stork, 2018), while natural scientists are simply too few (Tewksbury et al., 2014). However, some recent technical advances may help us to overcome the main impediments related to data limitation and getting close to the goal of modelling the distribution of arthropods with more confidence.

Foremost, the emergence of ensembles of small models has proved promising to optimize the modelling of species for which few occurrences are available; this is achieved by combining a set of small bivariate models to create a consensus model that avoids overfitting (details in Breiner et al., 2015, 2018).

Second, modelling above the species level (Smith et al., 2019), for example by integrating data from related species when their niche overlap is large (Qiao et al., 2017), may be a useful shortcut to overcome a lack of distribution data in many circumstances.

Furthermore, the information age is characterized by the emergence of a myriad of types of digital data (summarized in Jarić et al., 2020) that may help to fill distribution data gaps, especially for easy-to-identify species. It was shown that photograph-sharing platforms and smartphone applications such as iNaturalist are valuable sources of species occurrences (Unger et al., 2020), even in the case of our focal groups (Jiménez-Valverde et al., 2019; Wang et al., 2018). Citizen science programmes are also a valuable source of distribution data, for example about swarms of ants (Hart et al., 2018) or common species of spiders (Hart et al., 2018). Recent modelling exercises based on similar alternative data sources have demonstrated their utility in obtaining realistic representations of niches and distributions for easy-to-identify taxa (Peña-Aguilera et al., 2019; Wang et al., 2018).

Finally, the recent advances in metabarcoding and environmental DNA is of major interest to overcome the issue of species detectability (Muha et al., 2017) and lack of invertebrate taxonomists (Hebert \& Gregory, 2005). Metabarcoding consists in identifying species using small DNA sequences that are highly variable between species and weakly variable within a given species. It is the basis of the environmental DNA approach, which consists in the identification of the species present in a given environment using the DNA left by individuals. Despite many technical challenges, environmental DNA and metabarcoding face becoming standard survey tools in ecology (Deiner et al., 2017; Liu, Clarke, et al., 2020; Liu, Blackburn, et al., 2020), including for ants, ground beetles and spiders (Kennedy et al., 2020; Piper et al., 2019; Toju \& Baba, 2018). Their ability to provide reliable absence data and to produce a massive amount of presence data is predicted to improve the efficiency of SDMs in the near future (Muha et al., 2017). Recently, for example, the use of environmental DNA has proved useful to forecast the spread of invasive species (Zhang et al., 2020) or to monitor the success of reintroduction programmes (Riaz et al., 2020). Large-scale projects including metabarcoding of terrestrial arthropod communities [e.g. LIFEPLAN (https://www.helsinki.fi/en/projects/lifeplan) and the Insect Biome Atlas (https://www.insectbiomeatlas.com)] are currently taking place and will provide an unprecedented data baseline for
SDMs. This will likely trigger the parallel development of tools to handle the big data era (Hallgren et al., 2016).

\section{2 | Micro-scale environmental predictors}

Gigantic leaps forward are being made in the development of microclimatic databases (Kearney et al., 2014), as well as approaches for downscaling temperature data at high resolutions from thermal images (Senior et al., 2019) or airborne light detection and ranging data (George et al., 2015). It is predicted that in the following years, the use of remote sensing-derived data will become the standard for modelling and mapping the microclimate (Zellweger et al., 2019), especially in invertebrate research where the use of similar highresolution data has already proved useful to achieve realistic conservation prioritization (Bombi et al., 2019).

Furthermore, our literature survey emphasizes that habitat, soil and other land use variables, although rarely used, are key features affecting the distribution of invertebrates. As in the case of climatic variables, there is a general paucity of raster data at a meaningful spatial resolution, although the availability of global-scale, high-resolution variables is growing (e.g. SoilTemp: Lembrechts et al., 2020; SoilGrid: Hengl et al., 2017). Once again, for specific studies, statistical downscaling and remote sensing may come to help; for example, the use of high-resolution habitat variables was essential to model the distribution of spiders in spatially complex alpine rocky lands (Mammola et al., 2019).

\section{8 | OPPORTUNITIES FOR SDM RESEARCH ON TERRESTRIAL INVERTEBRATES}

SDMs are often used as a simple, correlative way to estimate species ranges based on the realized niche, having large uncertainties and often over- or underfitting the real distribution. In an influential paper published 15 years ago, it was foreseen that SDMs may offer "more than simple habitat models" (Guisan \& Thuiller, 2005), by tackling biotic interactions, migration processes, dispersal limitations and (meta)population dynamics.

The challenges faced by conservation biologists today call for the development of more of these process-based models (or mechanistic models), providing causal explanations for the observed patterns (Briscoe et al., 2019). These can be defined as any model that mechanistically links model predictions and species fitness, measured either directly or indirectly using functional traits or environmental and biological interactions (e.g. competing or mutualistic species) (Kearney, 2006). This idea was reinforced by a seminal paper by Kearney and Porter (2009) calling for explicitly not only integrating physiological data in mechanistic niche modelling but also life history traits (including dispersal abilities and fitness).

Currently, there are proportionally more such studies for plants and marine invertebrates than animals (Chardon et al., 2020; Webb 
et al., 2020), because large spatial data sets needed for integrating physiological trait variation are available (Chown \& Gaston, 2016). While all these applications are still rare when it comes to terrestrial arthropods (see Maino et al., 2016), recently there have been studies that have addressed biotic interaction (Mammola \& Isaia, 2017), dispersal limitations (Monsimet et al., 2020) and metapopulation dynamics (Giezendanner et al., 2020), thereby showing promising directions for future research. Studies including probability of survival to different stresses such as cold (Cuddington et al., 2018) or desiccation (Barton et al., 2019) were also performed for particularly well-known groups, including lepidopterans and insects considered as pests. However, whereas mechanistic models are increasingly available, they have high data demands and thus cannot be routinely used for invertebrates (Viterbi et al., 2020), especially in terrestrial arthropods where, as previously discussed, the scarcity of data on natural history and the large number of species are a clear challenge. Some ideas towards a more mechanistic understanding of arthropod distributions are discussed in the following.

\section{1 | Integration of species attributes and traits in SDMs}

Species traits influence the outcome of SDMs in two ways. First, they themselves influence the distribution of species. Either in the present, past or future, the ability of species to adapt to certain conditions, their history, their relation with other species or their ability to disperse, all influence species distribution and its change in time (Diamond, 2018). Second, their traits may influence how complete or biased the known distribution data are and hence how adequate the modelled distributions for the different purposes are. Taking into account trait data before, during and after the modelling is therefore crucial for correct interpretation and to be aware of possible limitations (but see Beissinger \& Riddell, 2021, for cautionary arguments).

The recent upsurge in open source trait databases and projects [ants (Parr et al., 2017), ground beetles (Homburg et al., 2014) and spiders (Lowe et al., 2020; Pekár et al., 2021; Pekár, Černecká, et al., 2021)] offers an unprecedented data baseline to integrate trait variability in modelling exercises and develop mechanistic descriptions of species distributions and their changes through time. Accordingly, the integration of correlative distribution analyses and functional approaches has recently been advocated (Mammola et al., 2019; Thuiller et al., 2009; Wittmann et al., 2016), as it would make it possible to bridge the differences in biogeography and functional ecology-"functional biogeography" (Violle et al., 2014).

There are various ways to link correlative SDMs and traits (Kearney \& Porter, 2009). The most obvious one is a simple comparison between model outputs and trait variability, including the formulation of hypotheses about why these may concur or not. Examples in invertebrates are the positive relationship between predicted habitat suitability and body size found in spiders (Mammola et al., 2019), phenotype-environment associations observed in butterflies (Zaman et al., 2019) or the use of thermal physiology tests to define thermal safe zones in ants (Coulin et al., 2019).

With the aim of obtaining more meaningful and realistic prediction of biodiversity change, recently new modelling approaches that directly incorporate phenotypic plasticity and other functional traits into correlative modelling are being scrutinized (e.g. AdaptR; Bush et al., 2016; $\Delta$ TraitSDM; Garzón et al., 2019). In our view, one of the most flexible way to integrate traits in SDM is via the so-called spatial Bayesian species distribution model (Brewer et al., 2016), as a Bayesian framework offers the possibility to constraint modelling conditions using priors (e.g. thermal limits derived from ecophysiological data or other traits). Whereas the performance of the approach has been tested in a handful of invertebrate species thus far (e.g. Feng et al., 2020; Zhou et al., under review), similar tools will become increasingly useful as the availability of traits and computation power increase, leading to more realistic and evolutionary-driven predictions of biodiversity change.

\section{2 | Linking genetic data and distributions}

SDMs have been criticized, among other things, for not taking into account heterogeneity in the genetic structure of populations within the species range (Hampe \& Petit, 2005; Smith et al., 2019). Indeed, SDMs generally assume uniformity of responses to climate, ignoring local adaptations and intraspecific variations (Franken et al., 2018; Hereford, 2009; Wang et al., 2021; Zhang et al., 2021). Several recent studies have demonstrated that genetically informed SDMs improve climate change predictions because they incorporate possible local adaptations (Ikeda et al., 2017; Marcer et al., 2016). Instead of building SDMs based on species occurrence defined using standard taxonomy, one can model the distribution of each genetic unit of the population. The identification of these units can be achieved using traditional molecular markers such as amplified fragment-length polymorphisms, microsatellites and even single nucleotide polymorphisms (see below). For example, Marcer et al. (2016) built SDMs for each haplotype Arabidopsis thaliana (Brassicaceae) and found that even though most haplotype distribution ranges will shrink with global climate change, two of them will expand. Some authors also advocate the use of genetic data because it allows the production of real absence data (absence of a given genetic cluster), making it possible to fit logistic regressions and the incorporation of endogenous spatial autocorrelation (Gotelli \& Colwell, 2011). The recent advances in high-throughput sequencing techniques allow ecologists to collect single nucleotide polymorphism data (Peterson et al., 2012) for cluster identification at reasonable costs. Single nucleotide polymorphism provides fine-scale resolution of population genetic structure, which can then be incorporated into SDMs. To our knowledge, this has rarely been done on animal populations (but see Hu et al., 2021; Razgour et al., 2018) and has never been done on terrestrial arthropod species. 


\section{3 | Accounting for dispersal}

Using a correlative approach makes the inclusion of complex processes such as dispersal more difficult. While the inclusion of dispersal into SDMs has been advocated for more than 15 years (Seaborn et al., 2020) and can substantially improve model fit (Dormann, 2007), dispersal processes are still rarely taken into account. According to recent quantitative literature surveys, in the last two decades the proportion of SDM papers that included dispersal data in estimates of range shifts hovered around $20 \%$ (Holloway \& Miller, 2017; Seaborn et al., 2020). The available studies on arthropods either considered dispersal by including a buffer of reachable areas around presences based on species-specific dispersal abilities [e.g. long-distance dispersal via ballooning for spiders (Mammola \& Isaia, 2017)], or relied on more sophisticated approaches based on kernel distribution [e.g. model of butterfly accounting for both demography and dispersal via a kernel distribution (Singer et al., 2018)]. In general, these are rough estimations, given that dispersal is a complex phenomenon that is not trivial to integrate into SDMs (Thuiller et al., 2013). Indeed, dispersal is characterized by three phases (Clobert et al., 2009), that is departure, transfer and settlement, that the model should theoretically account for. Moreover, several factors can influence each of these phases (e.g. inbreeding, temperature development, body condition or starvation; on spiders, see Bonte, Lukáč, et al., 2008; Bonte, Travis, et al., 2008; Bonte et al., 2009), often acting synergistically.

Different approaches, with varying complexity levels, have been developed to integrate dispersal into SDMs-see Miller \& Holloway, 2015 for an overview of methods. The use of mechanistic models, which is highly data demanding, is rarely feasible for mega-diverse arthropod groups. Moreover, while models that include dispersal often outperform simpler models, an increase in the model complexity usually increases the uncertainty of the prediction (Zurell et al., 2016). With the possible exception of butterflies, a group that stands at the forefront of research on dispersal-explicit SDM (Habel et al., 2018; Singer et al., 2018), integration of dispersal is therefore largely ignored in modelling exercises for arthropod groups. Conversely, the majority of studies we reviewed modelled terrestrial arthropod distributions assuming either unlimited dispersal or no-dispersal scenarios. Whereas similar scenarios may be realistic in specific circumstances (e.g. a no-dispersal scenario may be a good assumption for soil and cave-dwelling species; Mammola \& Leroy, 2018), more often these extreme assumptions will result in modelling artefacts, such as under- or overestimating range shift and niche parameters (Holloway \& Miller, 2017). Bateman et al. (2013) emphasized that, even when data are scarce, working with dispersal scenarios between these two extremes often improves the realism of projections. For arthropods, when detailed data on dispersal are missing, one can approximate dispersal based on available literature or functional traits loosely related to dispersal (e.g. body size), in order to set more realistic thresholds in the maximum range a species may shift. Even such simple attempts may significantly improve temporal predictions by constraining the range of potentially suitable habitat that can be reached.

\section{9 | CONCLUSIONS}

Efforts to map the diversity of invertebrate life have been mostly concentrated in the last ten years, emphasizing how more and more entomologists and other scientists are beginning to incorporate SDMs into their research. In the light of our ignorance about the diversity, distribution and life history of most arthropods, these versatile tools are proving useful to fill some major knowledge gaps regarding their diversity patterns. The importance of similar endeavours becomes apparent when considering the accumulating evidence about the silent extinctions of invertebrates (Cardoso, Barton, et al., 2020; Eisenhauer et al., 2019; Wagner et al., 2021), the limited conservation efforts that are directed towards them (Cardoso, 2012; Mammides, 2019; Mammola et al., 2020; Milano et al., 2021) and the calls for solutions to these problems (Harvey et al., 2020; Samways et al., 2020).

Apart from the conservation implications of using SDMs to map arthropod diversity, we have shown how terrestrial arthropods may provide opportunities for advancing SDM research. Given that terrestrial arthropod distributions are strongly influenced by microclimatic conditions and microhabitat structure, they represent ideal candidates for testing novel modelling approaches. So far, this potential is still largely unexploited, and thus, we have discussed some recent avenues of research where the integration of different data sources may lead to mechanistic descriptions of key processes associated with species distributions. We are certain that our suggestions are a drop in the ocean when compared to what is currently available in terms of modelling possibilitiesmethodological advances in SDM-related theory are so quick that often it is difficult to keep pace. As brand new solutions to describe patterns and processes associated with species distribution are becoming available, we hope that this review will succeed in highlighting the potential of arthropods in SDM research and, in the future, that we will more often see them involved as protagonists in these developments.

\section{ACKNOWLEDGEMENTS}

We are grateful to Cathryn Primrose-Mathisen for proofreading our English. Dr. Tim Bonebrake provided useful suggestions on an earlier version. SM acknowledges support from the European Commission through Horizon 2020 Marie Skłodowska-Curie Actions (MSCA) individual fellowships (Grant No. 882221). JP was supported by "BOOST ERC" OPALE and by the SAD "PEPPS" (Région Bretagne). DL was supported by the SAD "PEPPS" (Région Bretagne).

\section{CONFLICT OF INTEREST}

None declared. 


\section{DATA AVAILABILITY STATEMENT}

The complete data set used for the analyses is available in Dryad (https://doi.org/10.5061/dryad.x95x69pk5). R code used for the analyses is available on GitLab (https://gitlab.com/DenisLafage/ sdm_review).

\section{ORCID}

Stefano Mammola (iD https://orcid.org/0000-0002-4471-9055 Jérémy Monsimet (iD https://orcid.org/0000-0001-9153-8401

\section{REFERENCES}

Agnarsson, I., Coddington, J. A., \& Kuntner, M. (2013). Systematics: Progress in the study of spider diversity and evolution. Spider Research in the 21st Century: Trends and Perspectives.

Anderson, S. C., Elsen, P. R., Hughes, B. B., Tonietto, R. K., Bletz, M. C., Gill, D. A., Holgerson, M. A., Kuebbing, S. E., MacKenzie, C. M. D., Meek, M. H., \& Veríssimo, D. (2021). Trends in ecology and conservation over eight decades. Frontiers in Ecology and the Environment, 19(5), 274-282. https://doi.org/10.1002/fee.2320

Angelov, B. (2019). Review of species distribution modeling opensource software. Researchgate Preprint. https://doi.org/10.13140/ RG.2.2.33804.67203

Araújo, M. B., Anderson, R. P., Barbosa, A. M., Beale, C. M., Dormann, C. F., Early, R., Garcia, R. A., Guisan, A., Maiorano, L., Naimi, B., O'Hara, R. B., Zimmermann, N. E., \& Rahbek, C. (2019). Standards for distribution models in biodiversity assessments. Science Advances, 5(1), eaat4858. https://doi.org/10.1126/sciadv. aat4858

Aria, M., \& Cuccurullo, C. (2017). bibliometrix: An R-tool for comprehensive science mapping analysis. Journal of Informetrics, 11(4), 959975. https://doi.org/10.1016/j.joi.2017.08.007

Barnosky, A. D., Matzke, N., Tomiya, S., Wogan, G. O. U., Swartz, B., Quental, T. B., Marshall, C., McGuire, J. L., Lindsey, E. L., Maguire, K. C., Mersey, B., \& Ferrer, E. A. (2011). Has the Earth's sixth mass extinction already arrived? Nature, 471(7336), 51-57. https://doi. org/10.1038/nature09678

Barton, M. G., Terblanche, J. S., \& Sinclair, B. J. (2019). Incorporating temperature and precipitation extremes into process-based models of African lepidoptera changes the predicted distribution under climate change. Ecological Modelling, 394, 53-65. https://doi. org/10.1016/j.ecolmodel.2018.12.017

Batagelj, V., \& Cerinšek, M. (2013). On bibliographic networks. Scientometrics, 96(3), 845-864. https://doi.org/10.1007/s1119 2-012-0940-1

Bateman, B. L., Murphy, H. T., Reside, A. E., Mokany, K., \& VanDerWal, J. (2013). Appropriateness of full-, partial- and no-dispersal scenarios in climate change impact modelling. Diversity and Distributions, 19(10), 1224-1234. https://doi.org/10.1111/ddi.12107

Beissinger, S. R., \& Riddell, E. A. (2021). Why are species' traits weak predictors of range shifts? Annual Review of Ecology, Evolution, and Systematics, 52(1), annurev-ecolsys-012021-092849. https://doi. org/10.1146/annurev-ecolsys-012021-092849

Bennett, J. M., Sunday, J., Calosi, P., Villalobos, F., Martínez, B., MolinaVenegas, R., Araújo, M. B., Algar, A. C., Clusella-Trullas, S., Hawkins, B. A., Keith, S. A., Kühn, I., Rahbek, C., Rodríguez, L., Singer, A., Morales-Castilla, I., \& Olalla-Tárraga, M. Á. (2021). The evolution of critical thermal limits of life on Earth. Nature Communications, 12(1), 1198. https://doi.org/10.1038/s41467-021-21263-8

Bombi, P., Gnetti, V., D'Andrea, E., De Cinti, B., Vigna Taglianti, A., Bologna, M. A., \& Matteucci, G. (2019). Identifying priority sites for insect conservation in forest ecosystems at high resolution: The potential of LiDAR data. Journal of Insect Conservation, 23(4), 689698. https://doi.org/10.1007/s10841-019-00162-w

Bonte, D., Clercq, N. D., Zwertvaegher, I., \& Lens, L. (2009). Repeatability of dispersal behaviour in a common dwarf spider: Evidence for different mechanisms behind short- and long-distance dispersal. Ecological Entomology, 34(2), 271-276. https://doi. org/10.1111/j.1365-2311.2008.01070.x

Bonte, D., Lukáč, M., \& Lens, L. (2008). Starvation affects pre-dispersal behaviour of Erigone spiders. Basic and Applied Ecology, 9(3), 308315. https://doi.org/10.1016/j.baae.2007.03.004

Bonte, D., Travis, J. M. J., De Clercq, N., Zwertvaegher, I., \& Lens, L. (2008). Thermal conditions during juvenile development affect adult dispersal in a spider. Proceedings of the National Academy of Sciences, 105(44), 17000-17005. https://doi.org/10.1073/ pnas. 0806830105

Booth, T. H. (2018). Why understanding the pioneering and continuing contributions of BIOCLIM to species distribution modelling is important. Austral Ecology, 43(8), 852-860. https://doi.org/10.1111/ aec.12628

Branco, V., Henriques, S., Rego, C., \& Cardoso, P. (2019). Species conservation profiles of spiders (Araneae) endemic to mainland Portugal. Biodiversity Data Journal, 7, e39315. https://doi.org/10.3897/ BDJ.7.e39315

Breiner, F. T., Guisan, A., Bergamini, A., \& Nobis, M. P. (2015). Overcoming limitations of modelling rare species by using ensembles of small models. Methods in Ecology and Evolution, 6(10), 1210-1218. https:// doi.org/10.1111/2041-210X.12403

Breiner, F. T., Nobis, M. P., Bergamini, A., \& Guisan, A. (2018). Optimizing ensembles of small models for predicting the distribution of species with few occurrences. Methods in Ecology and Evolution, 9(4), 802808. https://doi.org/10.1111/2041-210X.12957

Brereton, T. M., Cruickshanks, K. L., Risely, K., Noble, D. G., \& Roy, D. B. (2011). Developing and launching a wider countryside butterfly survey across the United Kingdom. Journal of Insect Conservation, 15(1), 279-290. https://doi.org/10.1007/s10841-010-9345-8

Brewer, M. J., O'Hara, R. B., Anderson, B. J., \& Ohlemüller, R. (2016). Plateau: A new method for ecologically plausible climate envelopes for species distribution modelling. Methods in Ecology and Evolution, 7(12), 1489-1502. https://doi.org/10.1111/2041-210X.12609

Briscoe, N. J., Elith, J., Salguero-Gómez, R., Lahoz-Monfort, J. J., Camac, J. S., Giljohann, K. M., Holden, M. H., Hradsky, B. A., Kearney, M. R., McMahon, S. M., Phillips, B. L., Regan, T. J., Rhodes, J. R., Vesk, P. A., Wintle, B. A., Yen, J. D. L., \& Guillera-Arroita, G. (2019). Forecasting species range dynamics with process-explicit models: Matching methods to applications. Ecology Letters, 22(11), 19401956. https://doi.org/10.1111/ele.13348

Burns, P., Clark, M., Salas, L., Hancock, S., Leland, D., Jantz, P., Dubayah, R., \& Goetz, S. (2020). Incorporating canopy structure from simulated GEDI lidar into bird species distribution models. Environmental Research Letters, 15, 095002. https://doi.org/10.1088/1748-9326/ ab80ee

Bush, A., Mokany, K., Catullo, R., Hoffmann, A., Kellermann, V., Sgrò, C., McEvey, S., \& Ferrier, S. (2016). Incorporating evolutionary adaptation in species distribution modelling reduces projected vulnerability to climate change. Ecology Letters, 19(12), 1468-1478. https:// doi.org/10.1111/ele.12696

Cardoso, P. (2012). Habitats directive species lists: Urgent need of revision. Insect Conservation and Diversity, 5(2), 169-174. https://doi. org/10.1111/j.1752-4598.2011.00140.x

Cardoso, P., Barton, P. S., Birkhofer, K., Chichorro, F., Deacon, C., Fartmann, T., Fukushima, C. S., Gaigher, R., Habel, J. C., Hallmann, C. A., Hill, M. J., Hochkirch, A., Kwak, M. L., Mammola, S., Ari Noriega, J., Orfinger, A. B., Pedraza, F., Pryke, J. S., Roque, F. O., ... Samways, M. J. (2020). Scientists' warning to humanity on insect extinctions. 
Biological Conservation, 242, 108426. https://doi.org/10.1016/j. biocon.2020.108426

Cardoso, P., Branco, V. V., Borges, P. A. V., Carvalho, J. C., Rigal, F., Gabriel, R., Mammola, S., Cascalho, J., \& Correia, L. (2020). Automated discovery of relationships, models and principles in ecology. Frontiers in Ecology and Evolution, 8, 530135. https://doi. org/10.1101/027839

Cardoso, P., Erwin, T. L., Borges, P. A. V., \& New, T. R. (2011). The seven impediments in invertebrate conservation and how to overcome them. Biological Conservation, 144(11), 2647-2655. https://doi. org/10.1016/j.biocon.2011.07.024

Cardoso, P., \& Leather, S. R. (2019). Predicting a global insect apocaIypse. Insect Conservation and Diversity, 12(4), 263-267. https://doi. org/10.1111/icad.12367

Chardon, N. I., Pironon, S., Peterson, M. L., \& Doak, D. F. (2020). Incorporating intraspecific variation into species distribution models improves distribution predictions, but cannot predict species traits for a wide-spread plant species. Ecography, 43(1), 60-74. https://doi.org/10.1111/ecog.04630

Chen, I.-C., Hill, J. K., Ohlemüller, R., Roy, D. B., \& Thomas, C. D. (2011). Rapid range shifts of species associated with high levels of climate warming. Science, 333(6045), 1024-1026. https://doi.org/10.1126/ science.1206432

Chown, S. L., \& Gaston, K. J. (2016). Macrophysiology-progress and prospects. Functional Ecology, 30(3), 330-344. https://doi. org/10.1111/1365-2435.12510

Christman, M. C., Doctor, D. H., Niemiller, M. L., Weary, D. J., Young, J. A., Zigler, K. S., \& Culver, D. C. (2016). Predicting the occurrence of cave-inhabiting fauna based on features of the earth surface environment. PLoS One, 11(8), e0160408. https://doi.org/10.1371/ journal.pone.0160408

Clark, J. A., \& May, R. M. (2002). Taxonomic bias in conservation research. Science, 297(5579), 191-192. https://doi.org/10.1126/scien ce.297.5579.191b

Clobert, J., Le Galliard, J.-F., Cote, J., Meylan, S., \& Massot, M. (2009). Informed dispersal, heterogeneity in animal dispersal syndromes and the dynamics of spatially structured populations. Ecology Letters, 12(3), 197-209. https://doi. org/10.1111/j.1461-0248.2008.01267.x

Colinet, H., Sinclair, B. J., Vernon, P., \& Renault, D. (2015). Insects in fluctuating thermal environments. Annual Review of Entomology, 60(1), 123-140. https://doi.org/10.1146/annurev-ento-010814-021017

Coulin, C., de la Vega, G. J., Chifflet, L., Calcaterra, L. A., \& Schilman, P. E. (2019). Linking thermo-tolerances of the highly invasive ant, Wasmannia auropunctata, to its current and potential distribution. Biological Invasions, 21(12), 3491-3504. https://doi.org/10.1007/ s10530-019-02063-0

Cuddington, K., Sobek-Swant, S., Crosthwaite, J. C., Lyons, D. B., \& Sinclair, B. J. (2018). Probability of emerald ash borer impact for Canadian cities and North America: A mechanistic model. Biological Invasions, 20(9), 2661-2677. https://doi.org/10.1007/s1053 0-018-1725-0

Decae, A., Mammola, S., Rizzo, P., \& Isaia, I. (2019). Systematics, ecology and distribution of the mygalomorph spider genus Cteniza Latreille, 1829 (Araneae, Mygalomorphae, Ctenizidae). Zootaxa, 4550(4), 499-524. https://doi.org/10.11646/zootaxa.4550.4.2

Deiner, K., Bik, H. M., Mächler, E., Seymour, M., Lacoursière-Roussel, A. Altermatt, F., Creer, S., Bista, I., Lodge, D. M., de Vere, N., Pfrender, M. E., \& Bernatchez, L. (2017). Environmental DNA metabarcoding: Transforming how we survey animal and plant communities. Molecular Ecology, 26(21), 5872-5895. https://doi.org/10.1111/ mec. 14350

Diamond, S. E. (2018). Contemporary climate-driven range shifts: Putting evolution back on the table. Functional Ecology, 32(7), 1652-1665. https://doi.org/10.1111/1365-2435.13095
Dormann, C. F. (2007). Promising the future? Global change projections of species distributions. Basic and Applied Ecology, 8(5), 387-397. https://doi.org/10.1016/j.baae.2006.11.001

Eisenhauer, N., Bonn, A., \& Guerra, A. C. (2019). Recognizing the quiet extinction of invertebrates. Nature Communications, 10(1), 50. https://doi.org/10.1038/s41467-018-07916-1

Elith, J., H. Graham, C., P. Anderson, R., Dudík, M., Ferrier, S., Guisan, A., J. Hijmans, R., Huettmann, F., R. Leathwick, J., Lehmann, A., Li, J., G. Lohmann, L., A. Loiselle, B., Manion, G., Moritz, C., Nakamura, M., Nakazawa, Y., McC. M. Overton, J., Townsend Peterson, A., ... E. Zimmermann, N. (2006). Novel methods improve prediction of species' distributions from occurrence data. Ecography, 29(2), 129-151. https://doi.org/10.1111/j.2006.0906-7590.04596.x

Elith, J., \& Leathwick, J. R. (2009). Species distribution models: Ecological explanation and prediction across space and time. Annual Review of Ecology, Evolution, and Systematics, 40(1), 677-697. https://doi. org/10.1146/annurev.ecolsys.110308.120159

Elith, J., Phillips, S. J., Hastie, T., Dudík, M., Chee, Y. E., \& Yates, C. J. (2011). A statistical explanation of MaxEnt for ecologists. Diversity and Distributions, 17(1), 43-57. https://doi. org/10.1111/j.1472-4642.2010.00725.x

Feng, X., Liang, Y., Gallardo, B., \& Papeş, M. (2020). Physiology in ecological niche modeling: Using zebra mussel's upper thermal tolerance to refine model predictions through Bayesian analysis. Ecography, 43(2), 270-282. https://doi.org/10.1111/ecog.04627

Ferretti, N. E., Soresi, D. S., González, A., \& Arnedo, M. (2019). An integrative approach unveils speciation within the threatened spider Calathotarsus simoni (Araneae: Mygalomorphae: Migidae). Systematics and Biodiversity, 17(5), 439-457. https://doi. org/10.1080/14772000.2019.1643423

Ficetola, G. F., Canedoli, C., \& Stoch, F. (2019). The Racovitzan impediment and the hidden biodiversity of unexplored environments. Conservation Biology, 33(1), 214-216. https://doi.org/10.1111/ cobi.13179

Fick, S. E., \& Hijmans, R. J. (2017). WorldClim 2: New 1-km spatial resolution climate surfaces for global land areas. International Journal of Climatology, 37(12), 4302-4315. https://doi.org/10.1002/joc.5086

Fourcade, Y., Besnard, A. G., \& Secondi, J. (2018). Paintings predict the distribution of species, or the challenge of selecting environmental predictors and evaluation statistics. Global Ecology and Biogeography, 27(2), 245-256. https://doi.org/10.1111/ geb.12684

Franken, O., Huizinga, M., Ellers, J., \& Berg, M. P. (2018). Heated communities: Large inter- and intraspecific variation in heat tolerance across trophic levels of a soil arthropod community. Oecologia, 186(2), 311-322. https://doi.org/10.1007/s00442-017-4032-z

Fukushima, C. S., Mendoza, J. I., West, R. C., Longhorn, S. J., Rivera, E., Cooper, E. W. T., Hénaut, Y., Henriques, S., \& Cardoso, P. (2019). Species conservation profiles of tarantula spiders (Araneae, Theraphosidae) listed on CITES. Biodiversity Data Journal, 7, e39342. https://doi.org/10.3897/BDJ.7.e39342

Garzón, M. B., Robson, T. M., \& Hampe, A. (2019). $\Delta$ TraitSDMs: Species distribution models that account for local adaptation and phenotypic plasticity. New Phytologist, 222(4), 1757-1765. https://doi. org/10.1111/nph.15716

George, A. D., Thompson, F. R., \& Faaborg, J. (2015). Using LiDAR and remote microclimate loggers to downscale near-surface air temperatures for site-level studies. Remote Sensing Letters, 6(12), 924-932. https://doi.org/10.1080/2150704X.2015.1088671

Giezendanner, J., Pasetto, D., Perez-Saez, J., Cerrato, C., Viterbi, R., Terzago, S., Palazzi, E., \& Rinaldo, A. (2020). Earth and field observations underpin metapopulation dynamics in complex landscapes: Near-term study on carabids. Proceedings of the National Academy of Sciences, 117(23), 12877-12884. https://doi.org/10.1073/ pnas. 1919580117 
Gotelli, N. J., \& Colwell, R. K. (2011). Estimating species richness. In M. Magurran A.E. B. J. (Ed.), Frontiers in measuring biodiversity. Oxford University Press. (Vol. 1-2, pp. 39-54).

Guisan, A., \& Thuiller, W. (2005). Predicting species distribution: Offering more than simple habitat models. Ecology Letters, 8(9), 993-1009. https://doi.org/10.1111/j.1461-0248.2005.00792.x

Guisan, A., Thuiller, W., \& Zimmermann, N. E. (2017). Habitat suitability and distribution models: With applications in R. Cambridge University Press. https://doi.org/10.1017/9781139028271

Guisan, A., Tingley, R., Baumgartner, J. B., Naujokaitis-Lewis, I., Sutcliffe, P. R., Tulloch, A. I. T., Regan, T. J., Brotons, L., McDonaldMadden, E., Mantyka-Pringle, C., Martin, T. G., Rhodes, J. R., Maggini, R., Setterfield, S. A., Elith, J., Schwartz, M. W., Wintle, B. A., Broennimann, O., Austin, M., ... Buckley, Y. M. (2013). Predicting species distributions for conservation decisions. Ecology Letters, 16(12), 1424-1435. https://doi.org/10.1111/ ele.12189

Habel, J. C., Teucher, M., \& Rödder, D. (2018). Mark-release-recapture meets species distribution models: Identifying micro-habitats of grassland butterflies in agricultural landscapes. PLoS One, 13(11), e0207052. https://doi.org/10.1371/journal.pone.0207052

Hallgren, W., Beaumont, L., Bowness, A., Chambers, L., Graham, E., Holewa, H., Laffan, S., Mackey, B., Nix, H., Price, J., Vanderwal, J., Warren, R., \& Weis, G. (2016). The biodiversity and climate change virtual laboratory: Where ecology meets big data. Environmental Modelling \& Software, 76, 182-186. https://doi.org/10.1016/j.envso ft.2015.10.025

Halsch, C. A., Shapiro, A. M., Fordyce, J. A., Nice, C. C., Thorne, J. H., Waetjen, D. P., \& Forister, M. L. (2021). Insects and recent climate change. Proceedings of the National Academy of Sciences, 118(2), e2002543117. https://doi.org/10.1073/pnas.2002543117

Hamilton, C. A., Hendrixson, B. E., \& Bond, J. E. (2016). Taxonomic revision of the tarantula genus Aphonopelma Pocock, 1901 (Araneae, Mygalomorphae, Theraphosidae) within the United States. ZooKeys, 560, 1-340. https://doi.org/10.3897/zookeys.560.6264

Hampe, A., \& Petit, R. J. (2005). Conserving biodiversity under climate change: The rear edge matters. Ecology Letters, 8(5), 461-467. https://doi.org/10.1111/j.1461-0248.2005.00739.x

Hart, H. G., Hesselberg, T., Nesbit, R., \& Goodenough, A. E. (2018). The spatial distribution and environmental triggers of ant mating flights: Using citizen-science data to reveal national patterns. Ecography, 41(6), 877-888. https://doi.org/10.1111/ecog.03140

Hart, H. G., Nesbit, R., \& Goodenough, A. E. (2018). Spatiotemporal variation in house spider phenology at a national scale using citizen science. Arachnology, 17(7), 331-334. https://doi.org/10.13156/ arac.2017.17.7.331

Harvey, J. A., Heinen, R., Armbrecht, I., Basset, Y., Baxter-Gilbert, J. H., Bezemer, T. M., Böhm, M., Bommarco, R., Borges, P. A. V., Cardoso, P., Clausnitzer, V., Cornelisse, T., Crone, E. E., Dicke, M., Dijkstra, K.-D., Dyer, L., Ellers, J., Fartmann, T., Forister, M. L., ... de Kroon, H. (2020). International scientists formulate a roadmap for insect conservation and recovery. Nature Ecology \& Evolution, 4(2), 174176. https://doi.org/10.1038/s41559-019-1079-8

Hebert, P. D. N., \& Gregory, T. R. (2005). The promise of DNA barcoding for taxonomy. Systematic Biology, 54(5), 852-859. https://doi. org/10.1080/10635150500354886

Hellmann, J. J., Byers, J. E., Bierwagen, B. G., \& Dukes, J. S. (2008). Five potential consequences of climate change for invasive species. Conservation Biology, 22(3), 534-543. https://doi. org/10.1111/j.1523-1739.2008.00951.x

Hengl, T., de Jesus, J. M., Heuvelink, G. B. M., Gonzalez, M. R., Kilibarda, M., Blagotić, A., Shangguan, W., Wright, M. N., Geng, X., BauerMarschallinger, B., Guevara, M. A., Vargas, R., MacMillan, R. A., Batjes, N. H., Leenaars, J. G. B., Ribeiro, E., Wheeler, I., Mantel, S., \& Kempen, B. (2017). SoilGrids250m: Global gridded soil information based on machine learning. PLoS One, 12(2), e0169748. https://doi. org/10.1371/journal.pone.0169748

Hereford, J. (2009). A quantitative survey of local adaptation and fitness trade-offs. The American Naturalist, 173(5), 579-588. https://doi. org/10.1086/597611

Hijmans, R. J., Cameron, S. E., Parra, J. L., Jones, P. G., \& Jarvis, A. (2005). Very high resolution interpolated climate surfaces for global land areas. International Journal of Climatology, 25(15), 1965-1978. https://doi.org/10.1002/joc.1276

Holloway, P., \& Miller, J. A. (2017). A quantitative synthesis of the movement concepts used within species distribution modelling. Ecological Modelling, 356, 91-103. https://doi.org/10.1016/j.ecolm odel.2017.04.005

Holway, D. A., Lach, L., Suarez, A. V., Tsutsui, N. D., \& Case, T. J. (2002). The causes and consequences of ant invasions. Annual Review of Ecology and Systematics, 33(1), 181-233. https://doi.org/10.1146/ annurev.ecolsys.33.010802.150444

Homburg, K., Homburg, N., Schäfer, F., Schuldt, A., \& Assmann, T. (2014). Carabids.org - A dynamic online database of ground beetle species traits (Coleoptera, Carabidae). Insect Conservation and Diversity, 7(3), 195-205. https://doi.org/10.1111/icad.12045

Hortal, J., de Bello, F., Diniz-Filho, J. A. F., Lewinsohn, T. M., Lobo, J. M., \& Ladle, R. J. (2015). Seven shortfalls that beset large-scale knowledge of biodiversity. Annual Review of Ecology, Evolution, and Systematics, 46(1), 523-549. https://doi.org/10.1146/annurevecolsys-112414-054400

Høye, T. T., Ärje, J., Bjerge, K., Hansen, O. L. P., losifidis, A., Leese, F., Mann, H. M. R., Meissner, K., Melvad, C., \& Raitoharju, J. (2021). Deep learning and computer vision will transform entomology. Proceedings of the National Academy of Sciences, 118(2), e2002545117. https://doi.org/10.1073/pnas.2002545117

Hu, Z., Zhang, Q., Zhang, J., Kass, J. M., Mammola, S., Fresia, P., Draisma, S. G. A., Assis, J., Jueterbock, A., Yokota, M., \& Zhang, Z. (2021). Intraspecific genetic variation matters when predicting seagrass distribution under climate change. Molecular Ecology, 30(15), 38403855. https://doi.org/10.1111/mec.15996

Hughes, A. C., Orr, M. C., Ma, K., Costello, M. J., Waller, J., Provoost, P., Yang, Q., Zhu, C., \& Qiao, H. (2021). Sampling biases shape our view of the natural world. Ecography, 44(9), 1259-1269. https://doi. org/10.1111/ecog.05926

Hughes, M., Hornby, D. D., Bennion, H., Kernan, M., Hilton, J., Phillips, G., \& Thomas, R. (2004). The development of a GIS-based inventory of standing waters in Great Britain together with a risk-based prioritisation protocol. Water, Air, \& Soil Pollution: Focus, 4(2/3), 73-84. https://doi.org/10.1023/B:WAFO.0000028346.27904.83

Ikeda, D. H., Max, T. L., Allan, G. J., Lau, M. K., Shuster, S. M., \& Whitham, T. G. (2017). Genetically informed ecological niche models improve climate change predictions. Global Change Biology, 23(1), 164-176. https://doi.org/10.1111/gcb.13470

Jarić, I., Correia, R. A., Brook, B. W., Buettel, J. C., Courchamp, F., Di Minin, E., Firth, J. A., Gaston, K. J., Jepson, P., Kalinkat, G., Ladle, R., Soriano-Redondo, A., Souza, A. T., \& Roll, U. (2020). iEcology: Harnessing large online resources to generate ecological insights. Trends in Ecology \& Evolution, 35(7), 630-639. https://doi. org/10.1016/j.tree.2020.03.003

Jiménez-Valverde, A., Decae, A. E., \& Arnedo, M. A. (2011). Environmental suitability of new reported localities of the funnelweb spider Macrothele calpeiana: An assessment using potential distribution modelling with presence-only techniques. Journal of Biogeography, 38(6), 1213-1223. https://doi. org/10.1111/j.1365-2699.2010.02465.x

Jiménez-Valverde, A., Diniz, F., de Azevedo, E. B., \& Borges, P. A. V. (2009). Species distribution models do not account for abundance: The case of arthropods on Terceira island. Annales Zoologici Fennici, 46(6), 451-464. https://doi.org/10.5735/086.046.0606 
Jiménez-Valverde, A., Peña-Aguilera, P., Barve, V., \& Burguillo-Madrid, L. (2019). Photo-sharing platforms key for characterising niche and distribution in poorly studied taxa. Insect Conservation and Diversity, 12(5), 389-403. https://doi.org/10.1111/icad.12351

Karger, D. N., Conrad, O., Böhner, J., Kawohl, T., Kreft, H., Soria-Auza, R. W., Zimmermann, N. E., Linder, H. P., \& Kessler, M. (2017). Climatologies at high resolution for the earth's land surface areas. Scientific Data, 4(1), 170122. https://doi.org/10.1038/sdata.2017.122

Kearney, M. (2006). Habitat, environment and niche: What are we modelling? Oikos, 115(1), 186-191. https://doi. org/10.1111/j.2006.0030-1299.14908.x

Kearney, M. R., Isaac, A. P., \& Porter, W. P. (2014). microclim: Global estimates of hourly microclimate based on long-term monthly climate averages. Scientific Data, 1(1), 140006. https://doi.org/10.1038/ sdata.2014.6

Kearney, M., \& Porter, W. (2009). Mechanistic niche modelling: Combining physiological and spatial data to predict species' ranges. Ecology Letters, 12(4), 334-350. https://doi. org/10.1111/j.1461-0248.2008.01277.x

Kennedy, S. R., Prost, S., Overcast, I., Rominger, A. J., Gillespie, R. G., \& Krehenwinkel, H. (2020). High-throughput sequencing for community analysis: The promise of DNA barcoding to uncover diversity, relatedness, abundances and interactions in spider communities. Development Genes and Evolution, 230(2), 185-201. https://doi. org/10.1007/s00427-020-00652-x

Konno, K., Akasaka, M., Koshida, C., Katayama, N., Osada, N., Spake, R., \& Amano, T. (2020). Ignoring non-English-language studies may bias ecological meta-analyses. Ecology and Evolution, 10(13), 63736384. https://doi.org/10.1002/ece3.6368

Kriticos, D. J., Webber, B. L., Leriche, A., Ota, N., Macadam, I., Bathols, J., \& Scott, J. K. (2012). CliMond: Global high-resolution historical and future scenario climate surfaces for bioclimatic modelling. Methods in Ecology and Evolution, 3(1), 53-64. https://doi. org/10.1111/j.2041-210X.2011.00134.x

Krosby, M., Wilsey, C. B., McGuire, J. L., Duggan, J. M., Nogeire, T. M., Heinrichs, J. A., Tewksbury, J. J., \& Lawler, J. J. (2015). Climateinduced range overlap among closely related species. Nature Climate Change, 5(9), 883-886. https://doi.org/10.1038/nclim ate 2699

Leandro, C., Jay-Robert, P., \& Vergnes, A. (2017). Bias and perspectives in insect conservation: A European scale analysis. Biological Conservation, 215, 213-224. https://doi.org/10.1016/j. biocon.2017.07.033

Leather, S. R. (2009a). Taxonomic chauvinism threatens the future of entomology. Biologist, 56(1), 10-13.

Leather, S. R. (2009b). Institutional vertebratism threatens UK food security. Trends in Ecology \& Evolution, 24(8), 413-414. https://doi. org/10.1016/j.tree.2009.05.002

Lembrechts, J. J., Aalto, J., Ashcroft, M. B., De Frenne, P., Kopecký, M., Lenoir, J., Luoto, M., Maclean, I. M. D., Roupsard, O., Fuentes-Lillo, E., García, R. A., Pellissier, L., Pitteloud, C., Alatalo, J. M., Smith, S. W., Björk, R. G., Muffler, L., Ratier Backes, A., Cesarz, S., ... Nijs, I. (2020). SoilTemp: A global database of near-surface temperature. Global Change Biology, 26(11), 6616-6629. https://doi.org/10.1111/ gcb.15123

Lenoir, J., Bertrand, R., Comte, L., Bourgeaud, L., Hattab, T., Murienne, J., \& Grenouillet, G. (2020). Species better track climate warming in the oceans than on land. Nature Ecology \& Evolution, 1-16, https:// doi.org/10.1038/s41559-020-1198-2

Liu, M., Clarke, L. J., Baker, S. C., Jordan, G. J., \& Burridge, C. P. (2020). A practical guide to DNA metabarcoding for entomological ecologists. Ecological Entomology, 45(3), 373-385. https://doi.org/10.1111/ een.12831

Liu, X., Blackburn, T. M., Song, T., Wang, X., Huang, C., \& Li, Y. (2020). Animal invaders threaten protected areas worldwide. Nature
Communications, 11(1), 2892. https://doi.org/10.1038/s41467-02016719-2

Lobo, J. M., Jiménez-Valverde, A., \& Hortal, J. (2010). The uncertain nature of absences and their importance in species distribution modelling. Ecography, 33(1), 103-114. https://doi. org/10.1111/j.1600-0587.2009.06039.x

Lopes-Lima, M., Riccardi, N., Urbanska, M., Köhler, F., Vinarski, M., Bogan, A. E., \& Sousa, R. (2021). Major shortfalls impairing knowledge and conservation of freshwater molluscs. Hydrobiologia, 848(12), 28312867. https://doi.org/10.1007/s10750-021-04622-w

Lorenz, W. (2019). CarabCat: Global database of ground beetles (version Oct 2017). In Y. Roskov, G. Ower, T. Orrell, D. Nicolson, N. Bailly, P. M. Kirk, T. Bourgoin, R. E. DeWalt, W. Decock, E. van Nieukerken, J. Zarucchi, \& L. Penev (Eds.), Species 2000 \& ITIS catalogue of life, 2019 annual checklist. Species 2000: Naturalis. www.catalogueo flife.org/annual-checklist/2019. ISSN 2405-884X

Lowe, E. C., Wolff, J. O., Aceves-Aparicio, A., Birkhofer, K., Branco, V. V., Cardoso, P., Chichorro, F., Fukushima, C. S., GonçalvesSouza, T., Haddad, C. R., Isaia, M., Krehenwinkel, H., Audisio, T. L., Macías-Hernández, N., Malumbres-Olarte, J., Mammola, S. McLean, D. J., Michalko, R., Nentwig, W., ... Herberstein, M. E. (2020). Towards establishment of a centralized spider traits database. The Journal of Arachnology, 48(2), 103-109. https://doi. org/10.1636/0161-8202-48.2.103

Magalhaes, I. L. F., Oliveira, U., Santos, F. R., Vidigal, T. H. D. A., Brescovit, A. D., \& Santos, A. J. (2014). Strong spatial structure, Pliocene diversification and cryptic diversity in the Neotropical dry forest spider Sicarius cariri. Molecular Ecology, 23(21), 5323-5336.

Maino, J. L., Kong, J. D., Hoffmann, A. A., Barton, M. G., \& Kearney, M. R. (2016). Mechanistic models for predicting insect responses to climate change. Current Opinion in Insect Science, 17, 81-86. https:// doi.org/10.1016/j.cois.2016.07.006

Mammides, C. (2019). European Union's conservation efforts are taxonomically biased. Biodiversity and Conservation, 28(5), 1291-1296. https://doi.org/10.1007/s10531-019-01725-8

Mammola, S., Goodacre, S. L., \& Isaia, M. (2018). Climate change may drive cave spiders to extinction. Ecography, 41(1), 233-243. https:// doi.org/10.1111/ecog.02902

Mammola, S., \& Isaia, M. (2017). Rapid poleward distributional shifts in the European cave-dwelling Meta spiders under the influence of competition dynamics. Journal of Biogeography, 44(12), 2789-2797. https://doi.org/10.1111/jbi.13087

Mammola, S., Isaia, M., Arnedo, \& M. A. (2015). Alpine endemic spiders shed light on the origin and evolution of subterranean species. PeerJ, 3, e1384. https://doi.org/10.7717/peerj.1384

Mammola, S., \& Leroy, B. (2018). Applying species distribution models to caves and other subterranean habitats. Ecography, 41(7), 11941208. https://doi.org/10.1111/ecog.03464

Mammola, S., Milano, F., Vignal, M., Andrieu, J., \& Isaia, M. (2019). Associations between habitat quality, body size and reproductive fitness in the alpine endemic spider Vesubia jugorum. Global Ecology and Biogeography, 28(9), 1325-1335. https://doi.org/10.1111/ geb.12935

Mammola, S., Riccardi, N., Prié, V., Correia, R., Cardoso, P., Lopes-Lima, M., \& Sousa, R. (2020). Towards a taxonomically unbiased EU biodiversity strategy for 2030. Proceedings of the Royal Society B: Biological Sciences, 287, 20202166. https://doi.org/10.1098/ rspb.2020.2166

Marcer, A., Méndez-Vigo, B., Alonso-Blanco, C., \& Picó, F. X. (2016). Tackling intraspecific genetic structure in distribution models better reflects species geographical range. Ecology and Evolution, 6(7), 2084-2097. https://doi.org/10.1002/ece3.2010

Melo-Merino, S. M., Reyes-Bonilla, H., \& Lira-Noriega, A. (2020). Ecological niche models and species distribution models in marine environments: A literature review and spatial analysis of evidence. 
Ecological Modelling, 415, 108837. https://doi.org/10.1016/j.ecolm odel.2019.108837

Milano, F., Blick, T., Cardoso, P., Chatzaki, M., Fukushima, C. S., Gajdoš, P., Gibbons, A. T., Henriques, S., Macías-Hernández, N., Mammola, S., Nentwig, W., Nolan, M., Pétillon, J., Polchaninova, N., Řezáč, M., Sandström, J., Smith, H., Wiśniewski, K., \& Isaia, M. (2021). Spider conservation in Europe: A review. Biological Conservation, 256, 109020. https://doi.org/10.1016/j. biocon.2021.109020

Miller, J. A., \& Holloway, P. (2015). Incorporating movement in species distribution models. Progress in Physical Geography: Earth and Environment, 39(6), 837-849. https://doi.org/10.1177/0309133315580890

Monsimet, J., Devineau, O., Pétillon, J., \& Lafage, D. (2020). Explicit integration of dispersal-related metrics improves predictions of SDM in predatory arthropods. Scientific Reports, 10, 16668. https://doi. org/10.1038/s41598-020-73262-2

Muha, T. P., Rodríguez-Rey, M., Rolla, M., \& Tricarico, E. (2017). Using environmental DNA to improve species distribution models for freshwater invaders. Frontiers in Ecology and Evolution, 5, 158. https:// doi.org/10.3389/fevo.2017.00158

Muñoz, M. M., \& Bodensteiner, B. L. (2019). Janzen's hypothesis meets the Bogert effect: Connecting climate variation, thermoregulatory behavior, and rates of physiological evolution. Integrative Organismal Biology, 1(1), oby002. https://doi.org/10.1093/iob/oby002

Nentwig, W. (2015). Introduction, establishment rate, pathways and impact of spiders alien to Europe. Biological Invasions, 17(9), 27572778. https://doi.org/10.1007/s10530-015-0912-5

Ouzzani, M., Hammady, H., Fedorowicz, Z., \& Elmagarmid, A. (2016). Rayyan-a web and mobile app for systematic reviews. Systematic Reviews, 5(1), 1-10.

Parr, C. L., Dunn, R. R., Sanders, N. J., Weiser, M. D., Photakis, M., Bishop, T. R., Fitzpatrick, M. C., Arnan, X., Baccaro, F., Brandão, C. R. F., Chick, L., Donoso, D. A., Fayle, T. M., Gómez, C., Grossman, B., Munyai, T. C., Pacheco, R., Retana, J., Robinson, A., ... Gibb, H. (2017). GlobalAnts: A new database on the geography of ant traits (Hymenoptera: Formicidae). Insect Conservation and Diversity, 10(1), 5-20. https://doi.org/10.1111/icad.12211

Pavlek, M., \& Mammola, S. (2021). Niche-based processes explaining the distributions of closely related subterranean spiders. Journal of Biogeography, 48, 118-133. https://doi.org/10.1111/jbi.13987

Pekár, S., Wolff, J. O., Černecká, L'., Birkhofer, K., Mammola, S., Lowe, E. C., Fukushima, C. S., Herberstein, M. E., Kučera, A., Buzzatto, B. A., Djoudi, E. A., Domenech, M., Enciso, A. V., Piñanez Espejo, Y., Febles, S., García, L. F., Gonçalves-Souza, T., Isaia, M., Lafage, D., ... Cardoso, P. (2021). The World Spider Trait database: a centralized global open repository for curated data on spider traits. Database, baab064. https://doi.org/10.1093/database/baab064

Pekár, S., Černecká, L.., Wolff, J., Mammola, S., Cardoso, P., Lowe, E., Fukushima, C. S., Birkhofer, K., \& Herberstein, M. E. (2021). The world spider trait database v1.0. Masaryk University, Brno. https:// spidertraits.sci.muni.cz

Peña-Aguilera, P., Burguillo-Madrid, L., Barve, V., Aragón, P., \& JiménezValverde, A. (2019). Niche segregation in Iberian Argiope species. The Journal of Arachnology, 47(1), 37-44. https://doi. org/10.1636/0161-8202-47.1.37

Peterson, A. T. (2003). Predicting the geography of species' invasions via ecological niche modeling. The Quarterly Review of Biology, 78(4), 419-433. https://doi.org/10.1086/378926

Peterson, A. T. (2009). Phylogeography is not enough: The need for multiple lines of evidence. Frontiers of Biogeography, 1(1), 19-25. https://doi.org/10.21425/F5FBG12232

Peterson, A. T., \& Nakazawa, Y. (2008). Environmental data sets matter in ecological niche modelling: An example with Solenopsis invicta and Solenopsis richteri. Global Ecology and Biogeography, 17(1), 135-144. https://doi.org/10.1111/j.1466-8238.2007.00347.x
Peterson, B. K., Weber, J. N., Kay, E. H., Fisher, H. S., \& Hoekstra, H. E. (2012). Double digest RADseq: aninexpensive method for de novo SNP discovery and genotyping in model and non-modelspecies. PLOS ONE, 7(5), e37135

Phillips, S. J., Anderson, R. P., \& Schapire, R. E. (2006). Maximum entropy modeling of species geographic distributions. Ecological Modelling, 190(3), 231-259. https://doi.org/10.1016/j.ecolmodel.2005.03.026

Pichler, M., \& Hartig, F. (2021). A new joint species distribution model for faster and more accurate inference of species associations from big community data. Methods in Ecology and Evolution, 2041210X.13687. https://doi.org/10.1111/2041-210X.13687

Pincebourde, S., \& Woods, H. A. (2020). There is plenty of room at the bottom: Microclimates drive insect vulnerability to climate change. Current Opinion in Insect Science, 41, 63-70. https://doi. org/10.1016/j.cois.2020.07.001

Piper, A. M., Batovska, J., Cogan, N. O. I., Weiss, J., Cunningham, J. P., Rodoni, B. C., \& Blacket, M. J. (2019). Prospects and challenges of implementing DNA metabarcoding for high-throughput insect surveillance. GigaScience, 8(8), https://doi.org/10.1093/gigascience/giz092

Planas, E., Saupe, E. E., Lima-Ribeiro, M. S., Peterson, A. T., \& Ribera, C. (2014). Ecological niche and phylogeography elucidate complex biogeographic patterns in Loxosceles rufescens (Araneae, Sicariidae) in the Mediterranean Basin. BMC Evolutionary Biology, 14(1), 195. https://doi.org/10.1186/s12862-014-0195-y

Pol, M., Bailey, L. D., McLean, N., Rijsdijk, L., Lawson, C. R., \& Brouwer, L. (2016). Identifying the best climatic predictors in ecology and evolution. Methods in Ecology and Evolution, 7(10), 1246-1257. https:// doi.org/10.1111/2041-210X.12590

Potter, K. A., Woods, H. A., \& Pincebourde, S. (2013). Microclimatic challenges in global change biology. Global Change Biology, 19(10), 2932-2939. https://doi.org/10.1111/gcb.12257

Qiao, H., Peterson, A. T., Ji, L., \& Hu, J. (2017). Using data from related species to overcome spatial sampling bias and associated limitations in ecological niche modelling. Methods in Ecology and Evolution, 8(12), 1804-1812. https://doi.org/10.1111/2041-210X.12832

Qiao, H., Soberón, J., \& Peterson, A. T. (2015). No silver bullets in correlative ecological niche modelling: Insights from testing among many potential algorithms for niche estimation. Methods in Ecology and Evolution, 6(10), 1126-1136. https://doi. org/10.1111/2041-210X.12397

R Core Team. (2020). R: A language and environment for statistical computing. R Foundation for Statistical Computing. https://www.R-proje ct.org/

Razgour, O., Rebelo, H., Di Febbraro, M., \& Russo, D. (2016). Painting maps with bats: Species distribution modelling in bat research and conservation. Hystrix. https://doi.org/10.4404/hystrix-27.1-11753

Razgour, O., Taggart, J. B., Manel, S., Juste, J., Ibáñez, C., Rebelo, H., Alberdi, A., Jones, G., \& Park, K. (2018). An integrated framework to identify wildlife populations under threat from climate change. Molecular Ecology Resources, 18(1), 18-31. https://doi. org/10.1111/1755-0998.12694

Rezende, E. L., \& Bozinovic, F. (2019). Thermal performance across levels of biological organization. Philosophical Transactions of the Royal Society B: Biological Sciences, 374(1778), 20180549. https://doi. org/10.1098/rstb.2018.0549

Riaz, M., Kuemmerlen, M., Wittwer, C., Cocchiararo, B., Khaliq, I., Pfenninger, M., \& Nowak, C. (2020). Combining environmental DNA and species distribution modeling to evaluate reintroduction success of a freshwater fish. Ecological Applications, 30(2), e02034. https://doi.org/10.1002/eap.2034

Ripple, W. J., Wolf, C., Newsome, T. M., Barnard, P., \& Moomaw, W. R. (2020). World scientists' warning of a climate emergency. BioScience, 70(1), 8-12. https://doi.org/10.1093/biosci/biz088

Robinson, L. M., Elith, J., Hobday, A. J., Pearson, R. G., Kendall, B. E., Possingham, H. P., \& Richardson, A. J. (2011). Pushing the limits in 
marine species distribution modelling: Lessons from the land present challenges and opportunities. Global Ecology and Biogeography, 20(6), 789-802. https://doi.org/10.1111/j.1466-8238.2010.00636.x

Robinson, N. M., Nelson, W. A., Costello, M. J., Sutherland, J. E., \& Lundquist, C. J. (2017). A systematic review of marine-based species distribution models (SDMs) with recommendations for best practice. Frontiers in Marine Science, 4, 421. https://doi.org/10.3389/ fmars.2017.00421

Rödder, D., Weinsheimer, F., \& Lötters, S. (2010). Molecules meet macroecology-Combining species distribution models and phylogeographic studies. Zootaxa, 2426(1), 54-60. https://doi. org/10.11646/zootaxa.2426.1.3

Román-Palacios, C., \& Wiens, J. J. (2020). Recent responses to climate change reveal the drivers of species extinction and survival. Proceedings of the National Academy of Sciences, 117(8), 4211-4217. https://doi.org/10.1073/pnas.1913007117

Ross, K. G., Gotzek, D., Ascunce, M. S., \& Shoemaker, D. D. (2010). Species delimitation: A case study in a problematic ant taxon. Systematic Biology, 59(2), 162-184. https://doi.org/10.1093/sysbio/syp089

Roura-Pascual, N., Brotons, L., Peterson, A. T., \& Thuiller, W. (2009). Consensual predictions of potential distributional areas for invasive species: A case study of Argentine ants in the Iberian Peninsula. Biological Invasions, 11(4), 1017-1031. https://doi.org/10.1007/ s10530-008-9313-3

Roura-Pascual, N., Suarez, A. V., Gómez, C., Pons, P., Touyama, Y., Wild, A. L., \& Peterson, A. T. (2004). Geographical potential of Argentine ants (Linepithema humile Mayr) in the face of global climate change. Proceedings of the Royal Society of London. Series B: Biological Sciences, 271(1557), 2527-2535. https://doi.org/10.1098/rspb.2004.2898

Roura-Pascual, N., Suarez, A. V., McNyset, K., Gómez, C., Pons, P., Touyama, Y., Wild, A. L., Gascon, F., \& Peterson, A. T. (2006). Niche differentiation and fine-scale projections for argentine ants based on remotely sensed data. Ecological Applications, 16(5), 1832-1841.

Ryo, M., Angelov, B., Mammola, S., Kass, J. M., Benito, B. M., \& Hartig, F. (2021). Explainable artificial intelligence enhances the ecological interpretability of black-box species distribution models. Ecography, 44(2), 199-205. https://doi.org/10.1111/ecog.05360

Samways, M. J., Barton, P. S., Birkhofer, K., Chichorro, F., Deacon, C., Fartmann, T., Fukushima, C. S., Gaigher, R., Habel, J. C., Hallmann, C. A., Hill, M. J., Hochkirch, A., Kaila, L., Kwak, M. L., Maes, D., Mammola, S., Noriega, J. A., Orfinger, A. B., Pedraza, F., ... Cardoso, P. (2020). Solutions for humanity on how to conserve insects. Biological Conservation, 242, 108427. https://doi.org/10.1016/j. biocon.2020.108427

Santini, L., Antão, L. H., Jung, M., Benítez-López, A., Rapacciuolo, G., Di Marco, M., Jones, F. A. M., Haghkerdar, J. M., \& González-Suárez, M. (2021). The interface between macroecology and conservation: Existing links and untapped opportunities. Frontiers of Biogeography, 13(4), e53025. https://doi.org/10.21425/F5FBG53025

Santini, L., Benítez-López, A., Čengić, M., Maiorano, L., \& Huijbregts, M. A. J. (2021). Assessing the reliability of species distribution projections in climate change research. Diversity \& Distribution, 27(6), 1035-1050. https://doi.org/10.1111/ddi.13252

Schröder, B. (2008). Challenges of species distribution modeling belowground. Journal of Plant Nutrition and Soil Science, 171(3), 325-337. https://doi.org/10.1002/jpln.200700027

Seaborn, T. J., Goldberg, C. S., \& Crespi, E. J. (2020). Integration of dispersal data into distribution modeling: What have we done and what have we learned? Frontiers of Biogeography, 12(4), e43130. https:// doi.org/10.21425/F5FBG43130

Senior, R. A., Hill, J. K., \& Edwards, D. P. (2019). ThermStats: An R package for quantifying surface thermal heterogeneity in assessments of microclimates. Methods in Ecology and Evolution, 10(9), 1606-1614. https://doi.org/10.1111/2041-210X.13257
Seppälä, S., Henriques, S., Draney, M., Foord, S., Gibbons, A., Gomez, L., Kariko, S., Malumbres-Olarte, J., Milne, M., Vink, C., \& Cardoso, P. (2018a). Species conservation profiles of a random sample of world spiders II: Gnaphosidae to Nemesiidae. Biodiversity Data Journal, 6, e26203. https://doi.org/10.3897/BDJ.6.e26203

Seppälä, S., Henriques, S., Draney, M. L., Foord, S., Gibbons, A. T., Gomez, L. A., Kariko, S., Malumbres-Olarte, J., Milne, M., Vink, C. J., \& Cardoso, P. (2018b). Species conservation profiles of a random sample of world spiders I: Agelenidae to Filistatidae. Biodiversity Data Journal, 6, e23555. https://doi.org/10.3897/BDJ.6.e23555

Seppälä, S., Henriques, S., Draney, M. L., Foord, S., Gibbons, A. T., Gomez, L. A., Kariko, S., Malumbres-Olarte, J., Milne, M., Vink, C. J., \& Cardoso, P. (2018c). Species conservation profiles of a random sample of world spiders III: Oecobiidae to Salticidae. Biodiversity Data Journal, 6, e27004. https://doi.org/10.3897/BDJ.6.e27004

Seppälä, S., Henriques, S., Draney, M. L., Foord, S., Gibbons, A. T., Gomez, L. A., Kariko, S., Malumbres-Olarte, J., Milne, M., Vink, C. J., \& Cardoso, P. (2018d). Species conservation profiles of a random sample of world spiders IV: Scytodidae to Zoropsidae. Biodiversity Data Journal, 6, e30842. https://doi.org/10.3897/BDJ.6.e30842

Sillero, N. (2011). What does ecological modelling model? A proposed classification of ecological niche models based on their underlying methods. Ecological Modelling, 222(8), 1343-1346. https://doi. org/10.1016/j.ecolmodel.2011.01.018

Silverman, J., \& Brightwell, R. J. (2008). The Argentine ant: Challenges in managing an invasive unicolonial pest. Annual Review of Entomology, 53(1), 231-252. https://doi.org/10.1146/annurev.ento.53.103106.093450

Singer, A., Schweiger, O., Kühn, I., \& Johst, K. (2018). Constructing a hybrid species distribution model from standard large-scale distribution data. Ecological Modelling, 373, 39-52. https://doi. org/10.1016/j.ecolmodel.2018.02.002

Smith, A. B., Godsoe, W., Rodríguez-Sánchez, F., Wang, H.-H., \& Warren, D. (2019). Niche estimation above and below the species level. Trends in Ecology \& Evolution, 34(3), 260-273. https://doi. org/10.1016/j.tree.2018.10.012

Solomon, S. E., Bacci, M., Martins, J., Vinha, G. G., \& Mueller, U. G. (2008). Paleodistributions and comparative molecular phylogeography of leafcutter ants (Atta spp.) provide new insight into the origins of Amazonian diversity. PLoS One, 3(7), e2738. https://doi. org/10.1371/journal.pone.0002738

Staunton, K. M., Robson, S. K. A., Burwell, C. J., Reside, A. E., \& Williams, S. E. (2014). Projected distributions and diversity of flightless ground beetles within the Australian wet tropics and their environmental correlates. PLoS One, 9(2), e88635. https://doi.org/10.1371/journ al.pone.0088635

Steiner, F. M., Schlick-Steiner, B. C., VanDerWal, J., Reuther, K. D., Christian, E., Stauffer, C., Suarez, A. V., Williams, S. E., \& Crozier, R. H. (2008). Combined modelling of distribution and niche in invasion biology: A case study of two invasive Tetramorium ant species. Diversity and Distributions, 14(3), 538-545. https://doi. org/10.1111/j.1472-4642.2008.00472.x

Stork, N. E. (2018). How many species of insects and other terrestrial arthropods are there on Earth? Annual Review of Entomology, 63(1), 31-45. https://doi.org/10.1146/annurev-ento-020117-043348

Suggitt, A. J., Wilson, R. J., Isaac, N. J. B., Beale, C. M., Auffret, A. G., August, T., Bennie, J. J., Crick, H. Q. P., Duffield, S., Fox, R., Hopkins, J. J., Macgregor, N. A., Morecroft, M. D., Walker, K. J., \& Maclean, I. M. D. (2018). Extinction risk from climate change is reduced by microclimatic buffering. Nature Climate Change, 8(8), 713-717. https:// doi.org/10.1038/s41558-018-0231-9

Taucare-Ríos, A., Nentwig, W., Bizama, G., \& Bustamante, R. O. (2018). Matching global and regional distribution models of the recluse spider Loxosceles rufescens: To what extent do these reflect niche conservatism? Medical and Veterinary Entomology, 32(4), 490-496. https://doi.org/10.1111/mve.12311 
Tewksbury, J. J., Anderson, J. G. T., Bakker, J. D., Billo, T. J., Dunwiddie, P. W., Groom, M. J., Hampton, S. E., Herman, S. G., Levey, D. J., Machnicki, N. J., del Rio, C. M., Power, M. E., Rowell, K., Salomon, A. K., Stacey, L., Trombulak, S. C., \& Wheeler, T. A. (2014). Natural history's place in science and society. BioScience, 64(4), 300-310. https://doi.org/10.1093/biosci/biu032

Titley, M. A., Snaddon, J. L., \& Turner, E. C. (2017). Scientific research on animal biodiversity is systematically biased towards vertebrates and temperate regions. PLoS One, 12(12), e0189577. https://doi. org/10.1371/journal.pone.0189577

Toju, H., \& Baba, Y. G. (2018). DNA metabarcoding of spiders, insects, and springtails for exploring potential linkage between above- and below-ground food webs. Zoological Letters, 4(1), 4. https://doi. org/10.1186/s40851-018-0088-9

Tosa, M. I., Dziedzic, E. H., Appel, C. L., Urbina, J., Massey, A., Ruprecht, J., Eriksson, C. E., Dolliver, J. E., Lesmeister, D. B., Betts, M. G. Peres, C. A., \& Levi, T. (2021). The rapid rise of next-generation natural history. Frontiers in Ecology and Evolution, 9, 698131. https:// doi.org/10.3389/fevo.2021.698131

Thomas, C. D. (2010). Climate, climate change and range boundaries. Diversity and Distributions, 16(3), 488-495. https://doi. org/10.1111/j.1472-4642.2010.00642.x

Thomas, J. A. (2005). Monitoring change in the abundance and distribution of insects using butterflies and other indicator groups. Philosophical Transactions of the Royal Society B: Biological Sciences, 360(1454), 339-357. https://doi.org/10.1098/rstb.2004.1585

Thuiller, W., Albert, C. H., Dubuis, A., Randin, C., \& Guisan, A. (2009). Variation in habitat suitability does not always relate to variation in species' plant functional traits. Biology Letters, 6, 120-123. https:// doi.org/10.1098/rsbl.2009.0669

Thuiller, W., Guéguen, M., Renaud, J., Karger, D. N., \& Zimmermann, N. E. (2019). Uncertainty in ensembles of global biodiversity scenarios. Nature Communications, 10(1), 1446. https://doi.org/10.1038/ s41467-019-09519-w

Thuiller, W., Münkemüller, T., Lavergne, S., Mouillot, D., Mouquet, N., Schiffers, K., \& Gravel, D. (2013). A road map for integrating ecoevolutionary processes into biodiversity models. Ecology Letters, 16(s1), 94-105. https://doi.org/10.1111/ele.12104

Troudet, J., Grandcolas, P., Blin, A., Vignes-Lebbe, R., \& Legendre, F. (2017). Taxonomic bias in biodiversity data and societal preferences. Scientific Reports, 7(1), 1-14.

Trujillo, C. M., \& Long, T. M. (2018). Document co-citation analysis to enhance transdisciplinary research. Science Advances, 4(1), e1701130.

Unger, S., Rollins, M., Tietz, A., \& Dumais, H. (2020). iNaturalist as an engaging tool for identifying organisms in outdoor activities. Journal of Biological Education, 1-11. https://doi.org/10.1080/00219266.2020.1739114

van Swaay, C. A. M., Nowicki, P., Settele, J., \& van Strien, A. J. (2008). Butterfly monitoring in Europe: Methods, applications and perspectives. Biodiversity and Conservation, 17(14), 3455-3469. https://doi. org/10.1007/s10531-008-9491-4

Violle, C., Reich, P. B., Pacala, S. W., Enquist, B. J., \& Kattge, J. (2014). The emergence and promise of functional biogeography. Proceedings of the National Academy of Sciences USA, 111, 13690-13696. https:// doi.org/10.1073/pnas.1415442111

Viterbi, R., Cerrato, C., Bionda, R., \& Provenzale, A. (2020). Effects of temperature rise on multi-taxa distributions in mountain ecosystems. Diversity, 12(6), 210. https://doi.org/10.3390/d12060210

Wagner, D. L., Grames, E. M., Forister, M. L., Berenbaum, M. R., \& Stopak, D. (2021). Insect decline in the Anthropocene: Death by a thousand cuts. Proceedings of the National Academy of Sciences, 118(2), e2023989118. https://doi.org/10.1073/pnas.2023989118

Wang, X., Zhang, Z., Mammola, S., Ho, A. L. F. C., Yanhong, Z., Qin, G., \& Lin, Q. (2021). Exploring ecological specialization in pipefish using genomic, morphometric and ecological evidence. Diversity and Distributions, 27(8), 1393-1406. https://doi.org/10.1111/ddi.13286
Wang, Y., Casajus, N., Buddle, C., Berteaux, D., \& Larrivée, M. (2018). Predicting the distribution of poorly-documented species, Northern black widow (Latrodectus variolus) and Black purse-web spider (Sphodros niger), using museum specimens and citizen science data. PLoS One, 13(8), e0201094. https://doi.org/10.1371/ journal.pone.0201094

Warren, D. L. (2012). In defense of 'niche modeling'. Trends in Ecology \& Evolution, 27(9), 497-500. https://doi.org/10.1016/j.tree.2012.03.010

Webb, T. J., Lines, A., \& Howarth, L. M. (2020). Occupancy-derived thermal affinities reflect known physiological thermal limits of marine species. Ecology and Evolution, https://doi.org/10.1002/ece3.6407

Wickham, H. (2016). ggplot2: Elegant graphics for data analysis. Springer-Verlag.

Wittmann, M. E., Barnes, M. A., Jerde, C. L., Jones, L. A., \& Lodge, D. M. (2016). Confronting species distribution model predictions with species functional traits. Ecology and Evolution, 6, 873-879. https:// doi.org/10.1002/ece3.1898

World Spider Catalog. (2021). World Spider Catalog. Version 22.5. Natural History Museum Bern. http://wsc.nmbe.ch

Wüest, R. O., Zimmermann, N. E., Zurell, D., Alexander, J. M., Fritz, S. A., Hof, C., Kreft, H., Normand, S., Cabral, J. S., Szekely, E., Thuiller, W., Wikelski, M., \& Karger, D. N. (2020). Macroecology in the age of Big Data-Where to go from here? Journal of Biogeography, 47(1), 1-12. https://doi.org/10.1111/jbi.13633

Yates, K. L., Bouchet, P. J., Caley, M. J., Mengersen, K., Randin, C. F., Parnell, S., Fielding, A. H., Bamford, A. J., Ban, S., Barbosa, A. M., Dormann, C. F., Elith, J., Embling, C. B., Ervin, G. N., Fisher, R., Gould, S., Graf, R. F., Gregr, E. J., Halpin, P. N., ... Sequeira, A. M. M. (2018). Outstanding challenges in the transferability of ecological models. Trends in Ecology \& Evolution, 33(10), 790-802. https://doi. org/10.1016/j.tree.2018.08.001

Zaman, K., Hubert, M. K., Schoville, S. D. (2019). Testing the role of ecological selection on colour pattern variation in the butterfly Parnassius clodius. Molecular Ecology, 28(23), 5086-5102.

Zellweger, F., De Frenne, P., Lenoir, J., Rocchini, D., \& Coomes, D. (2019). Advances in microclimate ecology arising from remote sensing. Trends in Ecology \& Evolution, 34(4), 327-341. https://doi. org/10.1016/j.tree.2018.12.012

Zhang, J. (2017). Biodiversity science and macroecology in the era of big data. Biodiversity Science, 25(4), 355.

Zhang, L., Huettmann, F., Zhang, X., Liu, S., Sun, P., Yu, Z., \& Mi, C. (2019). The use of classification and regression algorithms using the random forests method with presence-only data to model species' distribution. MethodsX, 6, 2281-2292. https://doi.org/10.1016/j. mex.2019.09.035

Zhang, Z., Capinha, C., Usio, N., Weterings, R., Liu, X., Li, Y., Landeria, J. M., Zhou, Q., \& Yokota, M. (2020). Impacts of climate change on the global potential distribution of two notorious invasive crayfishes. Freshwater Biology, 65(3), 353-365. https://doi.org/10.1111/ fwb.13429

Zhang, Z., Kass, J. M., Mammola, S., Koizumi, I., Li, X., Tanaka, K., Ikeda, K., Suzuki, T., Yokota, M., \& Usio, N. (2021). Lineage-level distribution models lead to more realistic climate change predictions for a threatened crayfish. Diversity and Distributions, 27(4), 684-695. https://doi.org/10.1111/ddi.13225

Zhou, J., García Molinos, J., Mammola, S., Bede-Fazekas, Á., Feng, X., Kitazawa, D., \& Zhang, Z. 2021. (Under review). Incorporating physiological knowledge into correlative species distribution models improves biological realism and minimizes bias introduced by the choice of calibration area.

Zurell, D., Thuiller, W., Pagel, J., Cabral, J. S., Münkemüller, T., Gravel, D., Dullinger, S., Normand, S., Schiffers, K. H., Moore, K. A., \& Zimmermann, N. E. (2016). Benchmarking novel approaches for modelling species range dynamics. Global Change Biology, 22(8), 2651-2664. https://doi.org/10.1111/gcb.13251 


\section{BIOSKETCHES}

Stefano Mammola is an ecologist interested in different modelling methods. He uses simplified ecological settings, especially caves, as scalable model systems in which to minimize confounding effects and reduce the number of parameters needed to explore different eco-evolutionary processes.

Denis Lafage is a researcher focusing on community ecology and food webs of interface habitats. He is particularly interested in community response to perturbations both natural and humaninduced at local and landscape scales.

Author contributions: SM, JP and DL conceived the study. SM, $\mathrm{AH}, \mathrm{S}-\mathrm{LM}$ and $\mathrm{DL}$ mined and extracted information from papers. DL curated data, performed analyses and prepared figures. SM and DL wrote the first draft of the paper, with substantial inputs by JP, JM and PC. All authors contributed critically to the paper by means of discussions, comments and additions to the text.

\section{SUPPORTING INFORMATION}

Additional supporting information may be found in the online version of the article at the publisher's website.

How to cite this article: Mammola, S., Pétillon, J., Hacala, A., Monsimet, J., Marti, S.-L., Cardoso, P., \& Lafage, D. (2021).

Challenges and opportunities of species distribution modelling of terrestrial arthropod predators. Diversity and Distributions,

27, 2596-2614. https://doi.org/10.1111/ddi.13434 